\title{
Group II Metabotropic Glutamate Receptor Agonist Ameliorates MK80I-Induced Dysfunction of NMDA Receptors via the Akt/GSK-3 $\beta$ Pathway in Adult Rat Prefrontal Cortex
}

\author{
Dong $\mathrm{Xi}^{1,2,4}$, Yan-Chun $\mathrm{Li}^{1,4}$, Melissa A Snyder ${ }^{1,4}$, Ruby Y Gao ${ }^{3}$, Alicia E Adelman', Wentong Zhang², \\ Jed S Shumsky' and Wen-Jun Gao' \\ 'Department of Neurobiology and Anatomy, Drexel University College of Medicine, Philadelphia, PA, USA; ${ }^{2}$ Department of Pediatric Surgery, \\ Qilu Hospital of Shandong University, Shandong, China; ${ }^{3}$ School of Arts and Sciences, Washington University in St Louis, St Louis, MO, USA
}

\begin{abstract}
Pharmacological intervention targeting mGluRs has emerged as a potential treatment for schizophrenia, whereas the mechanisms involved remain elusive. We explored the antipsychotic effects of an mGluR2/3 agonist in the MK-80I model of schizophrenia in the rat prefrontal cortex. We found that the mGluR2/3 agonist LY379268 effectively recovered the disrupted expression of NMDA receptors induced by MK-80I administration. This effect was attributable to the direct regulatory action of LY379268 on NMDA receptors via activation of the Akt/GSK-3 $\beta$ signaling pathway. As occurs with the antipsychotic drug clozapine, acute treatment with LY379268 significantly increased the expression and phosphorylation of NMDA receptors, as well as Akt and GSK-3 $\beta$. Physiologically, LY379268 significantly enhanced NMDA-induced current in prefrontal neurons and a GSK-3 $\beta$ inhibitor occluded this effect. In contrast to the widely proposed mechanism of modulating presynaptic glutamate release, our results strongly argue that mGluR2/3 agonists modulate the function of NMDA receptors through postsynaptic actions and reverse the MK-80 I-induced NMDA dysfunction via the Akt/GSK-3 $\beta$ pathway. This study provides novel evidence for postsynaptic mechanisms of mGluR2/3 in regulation of NMDA receptors and presents useful insights into the mechanistic actions of mGluR2/3 agonists as potential antipsychotic agents for treating schizophrenia. Neuropsychopharmacology (20II) 36, 1260-1274; doi:10.1038/npp.201 I.12; published online I6 February 201 I
\end{abstract}

Keywords: Antipsychotics; metabolic glutamate receptors; NMDA receptors; NMDA antagonism; signaling pathway; schizophrenia

\section{INTRODUCTION}

Pharmacological intervention targeting metabotropic glutamate receptors (mGluRs) has emerged as a potential treatment for schizophrenia (Conn et al, 2009; Imre, 2007; Moghaddam, 2004; Patil et al, 2007; Weinberger, 2007). Recent studies indicate that mGluR2/3 agonists reverse the behavioral effects of the $N$-methyl-D-aspartic acid (NMDA) receptor antagonists phencyclidine (PCP) and dizocilpine (MK-801) in animal models and in patients with schizophrenia (Benneyworth et al, 2007; Cartmell et al, 2000a; Fell et al, 2008; Moghaddam and Adams, 1998; Olszewski et al, 2008; Patil et al, 2007; Schlumberger et al, 2009; Swanson and Schoepp, 2002; Woolley et al, 2008). These studies suggest that mGluR2/3 agonists have antipsychotic

Correspondence: Dr W-J Gao, Department of Neurobiology and Anatomy, Drexel University College of Medicine, 2900 Queen Lane, Philadelphia, PA 19129, USA, Tel: + 215 99| 8907, Fax: + 215843 9082, E-mail:wgao@drexelmed.edu

${ }^{4}$ These authors contribute equally to this work.

Received 23 June 20 I0; revised I January 20 I ; accepted I 3 January 2011 properties and may offer promise for a new class of nondopaminergic therapeutics for the treatment of schizophrenia (Conn et al, 2008; Weinberger, 2007). The findings are exciting, but important questions remain: why do mGluR2/3 agonists have the same therapeutic efficacy as D2 receptor antipsychotic agents and by what mechanisms do mGluR2/3 agonists ameliorate schizophrenic behaviors?

The hypothesis of NMDA hypofunction for schizophrenia is based on the observations that NMDAR antagonists, such as phencyclidine, ketamine, and dizocilpine (MK-801), are able to produce a pattern of neurochemical and behavioral changes that are similar to those seen in schizophrenia in both animal models and human subjects (Farber, 2003; Javitt, 2004; Javitt and Zukin, 1991; Jentsch and Roth, 1999; Krystal et al, 1994, 1999; Lahti et al, 1995; Marino and Conn, 2002; Moghaddam, 2003; Olney and Farber, 1995). In a recent study, we reported an inverted- $U$ dose-dependent alterations of NMDAR mRNA and differential protein expressions of NR2A and NR2B subunits in MK-801-treated rat prefrontal cortex (PFC) (Xi et al, 2009b). Our results reconciled many discrepancies reported in previous studies in the MK-801 model, suggesting that MK-801 treatment 
increased the expression of NMDARs at low concentrations (Gao and Tamminga, 1995; Rujescu et al, 2006; Wang et al, 1999), but decreased their expression at high doses (Harris et al, 2003; Lindahl and Keifer, 2004). We reasoned that mGluR2/3 agonists may reverse the behavioral effects of NMDAR antagonists by directly affecting NMDAR expression and function. Recent studies provide some evidence for this and indicated that mGluR2/3 agonists significantly enhanced NMDA-induced current in dissociated culture neurons (Tyszkiewicz et al, 2004) and in prefrontal cortical slices under conditions of blockade of glutamate transporters (Oliveira et al, 2008). However, it remains unknown how the mGluR2/3 agonist affects the expression and function of NMDA receptors in the animal model of NMDA receptor antagonist. Phosphorylation of NR2B on Tyr1472 disrupts the interaction between NMDA receptors and the AP2-clathrin endocytic complex, leading to stabilization of the receptor on the cell surface (Barki-Harrington et al, 2009; Zhang et al, 2008); whereas phosphorylation of NR2B at Ser1303 results in either disruption of NR2B-CaMKII complex and inhibition of NMDA currents (Liu et al, 2006) or potentiation of NMDA current by PKC (Liao et al, 2001). Does mGluR2/3 agonists directly interact with NMDA receptors or are their effects mediated indirectly via activation of an intracellular signaling pathway?

One candidate signaling pathway is the AKT/GSK-3 (glycogen synthase kinase-3) pathway. Previous work suggested that GSK-3 (particularly GSK-3 $\beta$ ) has an important role in the pathogenesis of schizophrenia (Emamian et al, 2004; Jope and Roh, 2006) and acts as a common signaling pathway for diverse psychotomimetic agents, including D-amphetamine, D-lysergic acid diethylamide (LSD), and PCP (Svenningsson et al, 2003). Akt is one of the principal kinase inhibitors of GSK-3 $\beta$. Incresed activity of either Akt or its phosphorylation of Ser473 will inhibit GSK-3 $\beta$ kinase activity. In addition, $N$-terminal serine phosphorylation of GSK- $3 \beta$ also inactivate GSK-3 $\beta$ kinase and thus decrease the activity (Jope and Roh, 2006; Koros and Dorner-Ciossek, 2007). Furthermore, it has been reported that stimulation of NMDA receptors with NMDA can activate GSK-3 $\beta$ by decreasing the phosphorylation of Akt (Luo et al, 2003). Moreover, converging evidence suggests impaired Akt/GSK-3 $\beta$ signaling in schizophrenia (Emamian et al, 2004; Kozlovsky et al, 2002, 2005). We therefore hypothesized that mGluR2/3 agonists restore the disrupted NMDA receptor function induced by the MK-801 blockade in vivo through regulation of NMDA receptors in the PFC to improve schizophrenic symptoms and to change behaviors. We tested this hypothesis and demonstrated that mGluR2/3 agonists may modulate the function of NMDA receptors through postsynaptic actions and reverse the MK801-induced NMDA dysfunction via activation of the Akt/ GSK-3 $\beta$ pathway.

\section{MATERIALS AND METHODS}

\section{Animals and Treatments}

We used 144 female Sprague-Dawley rats at $90 \pm 2$ days (250-278 g). The animals were cared for under the animal use guidelines of the National Institutes of Health, and the experimental protocol was approved by the Institutional
Animal Care and Use Committee at Drexel University College of Medicine. Female young adult Sprague-Dawley rats (3 months) were selected because PCP-, MK-801-, and ketamine-induced cortical injury is more reproducible in female and adult animals (Dickerson and Sharp, 2006; Farber et al, 1995; Nakki et al, 1996). Animals were allowed to adapt to the new environment for 2 days before we began the experiments. Acute treatment (single dose, intraperitoneal, i.p.): (1) clozapine $(5 \mathrm{mg} / \mathrm{kg}), \mathrm{mGluR} 2 / 3$ agonist LY379268 (0.3 or $3.0 \mathrm{mg} / \mathrm{kg})$, MK-801 (0.033 or $1 \mathrm{mg} / \mathrm{kg})$; (2) single-dose of $\mathrm{MK}-801(0.033,0.1$, or $1 \mathrm{mg} / \mathrm{kg}$, i.p.) followed by LY379268 $(0.3,1$, or $3 \mathrm{mg} / \mathrm{kg}$, i.p.) $50 \mathrm{~min}$ later; or LY379268 as pre-treatment $30 \mathrm{~min}$ before MK-801 administration. GSK inhibitor 3-(2, 4-dichlorophenyl)-4(1-methyl-1H-indol-3yl)-1H-pyrrole-2, 5-dione (SB216763, $1 \mathrm{mg} / \mathrm{kg}$, i.p.) was applied $30 \mathrm{~min}$ before MK-801 or LY379268. Saline solution ( $0.9 \%$ sodium chloride) was used as the vehicle control. Subchronic administration of MK-801 was performed by five consecutive daily injections of 0.033 or $1.0 \mathrm{mg} / \mathrm{kg}$, followed by LY379268 of 0.3 or $3.0 \mathrm{mg} / \mathrm{kg} 50 \mathrm{~min}$ after each MK-801 injection, with $0.9 \%$ saline as the vehicle control. We chose the dosage and time interval for MK-801 and LY379268 injections on the basis of previous electrophysiological and behavioral findings (Cartmell et al, 1999; Homayoun et al, 2005; Moghaddam and Adams, 1998) and those from our recent report (Xi et al, 2009b). Clozapine and MK-801 were obtained from Sigma-Aldrich; LY379268 and SB216763 were purchased from Tocris Bioscience. All animals were deeply anesthetized with Euthasol $(0.2 \mathrm{ml} / \mathrm{kg}$, Virbac Animal Health) and were immediately decapitated. Brain tissues containing medial and dorsal frontal cortex (with striatum excluded) were collected for western blot and medial PFC (prelimbic area) for electrophysiological recording. The tissues were taken $50 \mathrm{~min}$ after the drug injection.

\section{Western Blotting}

The PFC tissues were trimmed, weighed immediately, and homogenized in lysis buffer $(5 \mu \mathrm{l} / \mathrm{mg}, 20 \mathrm{mM}$ Tris-HCl with $\mathrm{pH}$ 7.4, $200 \mathrm{mM} \mathrm{NaCl}, 1 \mathrm{mM} \mathrm{Na} \mathrm{VO}_{4}, 10 \mathrm{mM} \mathrm{NaF}$, and protease inhibitor cocktail). After centrifugation at $13000 \mathrm{~g}$ for $15 \mathrm{~min}$ at $4^{\circ} \mathrm{C}$, the supernatant was transferred into new tubes, and the protein concentration was measured using a protein assay kit (Bio-Rad Laboratories). Each sample contained $10 \mu \mathrm{g}$ of protein that was dissolved in $10 \mu \mathrm{l}$ lysis buffer solution with $5 \mu \mathrm{l} 6 \times$ sample buffer and $0.5 \mu \mathrm{l}$ $\beta$-mercaptoethanol. The protein samples were boiled at $95^{\circ} \mathrm{C}$ for $3 \mathrm{~min}$, subjected to SDS-PAGE gel electrophoresis, and then transferred to nitrocellulous membranes (BioRad) overnight. The membranes were blocked with 5\% nonfat dry milk in TBST $(0.05 \%$ Tween-20 in $1 \times$ Tris-buffered saline) for $1 \mathrm{~h}$ and were incubated in the following dilutions of primary antibodies for $1 \mathrm{~h}$ : monoclonal mouse anti-NR2A and anti-NR2B (1:4000, Zymed/Invitrogen), monoclonal mouse antiactin (1:20000, Sigma-Aldrich), rabbit antipNR2B Tyr1472 (1:2000, Millipore), rabbit anti-pNR2B Ser1303 (1:2000, Millipore), and rabbit anti-GSK-3 $\beta$, rabbit anti-pGSK Ser9, rabbit anti-Akt, rabbit anti-pAkt Ser473 at 1:500-1000 (Cell Signaling). After several rinses with TBST, the membranes were incubated in horseradish peroxidase-conjugated goat anti-mouse or rabbit IgG (Jackson 
ImmunoResearch Laboratories) at 1:8000 for $2 \mathrm{~h}$. The immunopositive protein bands were detected with ECL Western Blotting System (Amersham Bioscience). After exposure of the membranes to the film, the band densities were measured with Image J (NIH). Final data were normalized to the levels of $\beta$-actin or total proteins (for phosphorylation) and then to the control levels with control as 1. To minimize interblot variability, each group included 4-5 rats and each sample from an animal was analyzed four times. The mean value for each sample was calculated from all of the replicates in the different animals, and the results were presented as mean \pm standard error. Significance was determined with the Student $t$ test or ANOVA.

\section{Immunoprecipitation}

Tissues containing PFC were microdissected and then homogenized in ice-cold NP-40 lysis buffer $(50 \mathrm{mM}$ Tris$\mathrm{HCl} \mathrm{pH} \mathrm{8.0,} 150 \mathrm{mM} \mathrm{NaCl}, 1 \% \mathrm{NP}-40$, and protease inhibitor cocktail) and centrifuged at $13000 \mathrm{~g}$ for $10 \mathrm{~min}$ at $4{ }^{\circ} \mathrm{C}$. Supernatant fractions $(500 \mu \mathrm{g}$ proteins $)$ were incubated overnight with $2.5 \mu \mathrm{g}$ of monoclonal antimGluR2/3 (Millipore) or anti-NR2B (BD Bioscience). The immuno-complexes were isolated by addition of 25-100 $\mu \mathrm{l}$ of protein G-sepharose beads (GE Healthcare Bio-Sciences $\mathrm{AB})$, followed by incubation for 3 to $4 \mathrm{~h}$ at $4^{\circ} \mathrm{C}$. The pellets were then washed four times with lysis buffer, resuspended in laemmli sample buffer, and boiled for $10 \mathrm{~min}$. After they were centrifuged at $10000 \mathrm{~g}$ for $5 \mathrm{~min}$, the supernatant was collected. The immunoprecipitated proteins were analyzed by western blot with antibodies against mGluR2/3 or NR2B. Wash-in supernatants that were treated with pellets of IP-NR2B or IP-mGluR2/3 after the IP samples were centrifuged and used as negative controls to avoid a false positive response.

\section{Electrophysiological Recoding in Prefrontal Cortical Slices}

Sprague-Dawley rats at postnatal day 12-30 were used for this study. The detailed procedure can be found in the reports of our previous studies (Li et al, 2009). The animals were deeply anesthetized with Euthasol $(0.2 \mathrm{ml} / \mathrm{kg})$, and the brains were removed immediately. The blocks of neocortex containing medial PFC were trimmed and were sectioned using Leica VT1000s Vibratome (Leica Microsystems, USA). Horizontal brain slices at a thickness of $300 \mu \mathrm{m}$ were incubated in oxygenated Ringer's solution at $35^{\circ} \mathrm{C}$ for $1 \mathrm{~h}$. The Ringer's solution contained the following ingredients (in $\mathrm{mM}$ ): $128 \mathrm{NaCl}, 2.5 \mathrm{KCl}, 1.25 \mathrm{NaH}_{2} \mathrm{PO}_{4}, 2 \mathrm{CaCl}_{2}, 1$ $\mathrm{MgSO}_{4}, 26 \mathrm{NaHCO}_{3}$, and 10 dextrose, $\mathrm{pH}$ 7.4. Whole-cell patch clamp recordings were conducted in the medial PFC through an upright Zeiss Axioskop 2 microscope (Carl Zeiss) equipped with optics of infrared-differential interference contrast and a digital video camera system. The recordings were conducted at $\sim 35^{\circ} \mathrm{C}$. The resistance of the recording pipette was 7-9 $\mathrm{M} \Omega$. A Cs + -solution containing (in $\mathrm{mM}$ ) $120 \mathrm{Cs}$-gluconate, 5 lidocaine (QX-314), $6 \mathrm{CsCl}_{2}$, 1 ATP-Mg, $0.2 \mathrm{Na}_{2} \mathrm{GTP}$, and 10 Hepes at $\mathrm{pH} 7.3$ (adjusted with $\mathrm{CsOH}$ ) was used to block sodium and potassium channels. NMDA was applied either by pressure puff $(100 \mu \mathrm{M})$ through a glass peptide $(\sim 2 \mathrm{M} \Omega)$ connected to a microinjector (PMI-100, Cornerstone series, Dagan) or by bath $(15 \mu \mathrm{M})$, NMDA-induced inward currents were recorded at $-60 \mathrm{mV}$ in the presence of CNQX $(20 \mu \mathrm{M})$ and picrotoxin $(50 \mu \mathrm{M})$. All chemicals were purchased from Sigma-Aldrich unless otherwise specified. The electric signals were amplified and filtered at $2 \mathrm{kHz}$ in voltage clamp mode with a MultiClamp 700B (Molecular Devices) and acquired through a DigiData 1322A (data acquisition system) and pCLAMP 9.2 software (Molecular Devices). The series resistances were compensated and were constantly monitored. The amplitudes of the NMDA-induced currents were measured with Clampfit 9.2 software (Molecular Devices).

\section{Total Activity Testing}

A SmartFrame open field activity box (Kinder Scientific, Poway, CA) containing 32 infrared photobeams in both the $\mathrm{X}$ and $\mathrm{Y}$ plane was used to assess the animal's activity level for $5 \mathrm{~min}$ starting at $60 \mathrm{~min}$ after the last injection. This system recorded each time any part of the animal's body crossed a photobeam and allowed us to determine the total activity level for each animal as the sum of its horizontal, vertical, and repetitive crossings. Female adult rats (PD90, $n=20$ ) were tested for baseline total activity, then randomly divided into two groups $(n=10$ each). One group received five daily IP injections of $0.033 \mathrm{mg} / \mathrm{kg} \mathrm{MK}-801$ and the control group received five daily IP injections of saline before retesting at the same time of the day as baseline testing. Total activity data are presented as the percent decrease from baseline. Data that were multiple SD from the mean were considered to be outliers and excluded from the data set, which resulted in $n=9$ per group. Data were analyzed by Student's $t$-test (unpaired, two-tailed) at a significance level of 0.05 .

\section{RESULTS}

\section{The mGluR2/3 Agonist LY379268 Recovered the Disrupted Expressions of NMDA Receptors Induced by Subchronic MK-801 Administration}

Although a clinical trial has reported that mGluR2/3 agonists could be a non-dopaminergic antipsychotic agent to treat schizophrenia, the mechanisms by which they operate remain unclear. To study whether the mGluR2/3 agonist LY379268 could reverse the disrupted functions of NMDA receptors induced by MK-801 treatment, we gave rats $\mathrm{MK}-801$ at two different i.p. doses (low dose, 0.033 $\mathrm{mg} / \mathrm{kg}$; high dose, $1 \mathrm{mg} / \mathrm{kg}$ ) once a day for 5 days (Xi et al, $2009 \mathrm{~b})$. We chose a relatively low dose of MK-801 at $0.033 \mathrm{mg} / \mathrm{kg}$ and high dose of $1 \mathrm{mg} / \mathrm{kg}$ because we previously reported that these two doses induced opposite changes of NMDA receptor subunits and $0.033 \mathrm{mg} / \mathrm{kg}$ was the most effective dosage in inducing alterations of NMDA receptor subunits compared with the intermediate dose of 0.1 or $0.33 \mathrm{mg} / \mathrm{kg}$ (Xi et al, 2009b). In addition, this relative low dosage is effective in affecting the locomotor activity as previous studies reported (Jackson et al, 2004; Tsukada et al, 2005; Winger et al, 1989). Indeed, daily treatment with MK-801 $(0.033 \mathrm{mg} / \mathrm{kg}$, once a day for 5 days $)$ resulted in a significant reduction in total activity compared with saline 

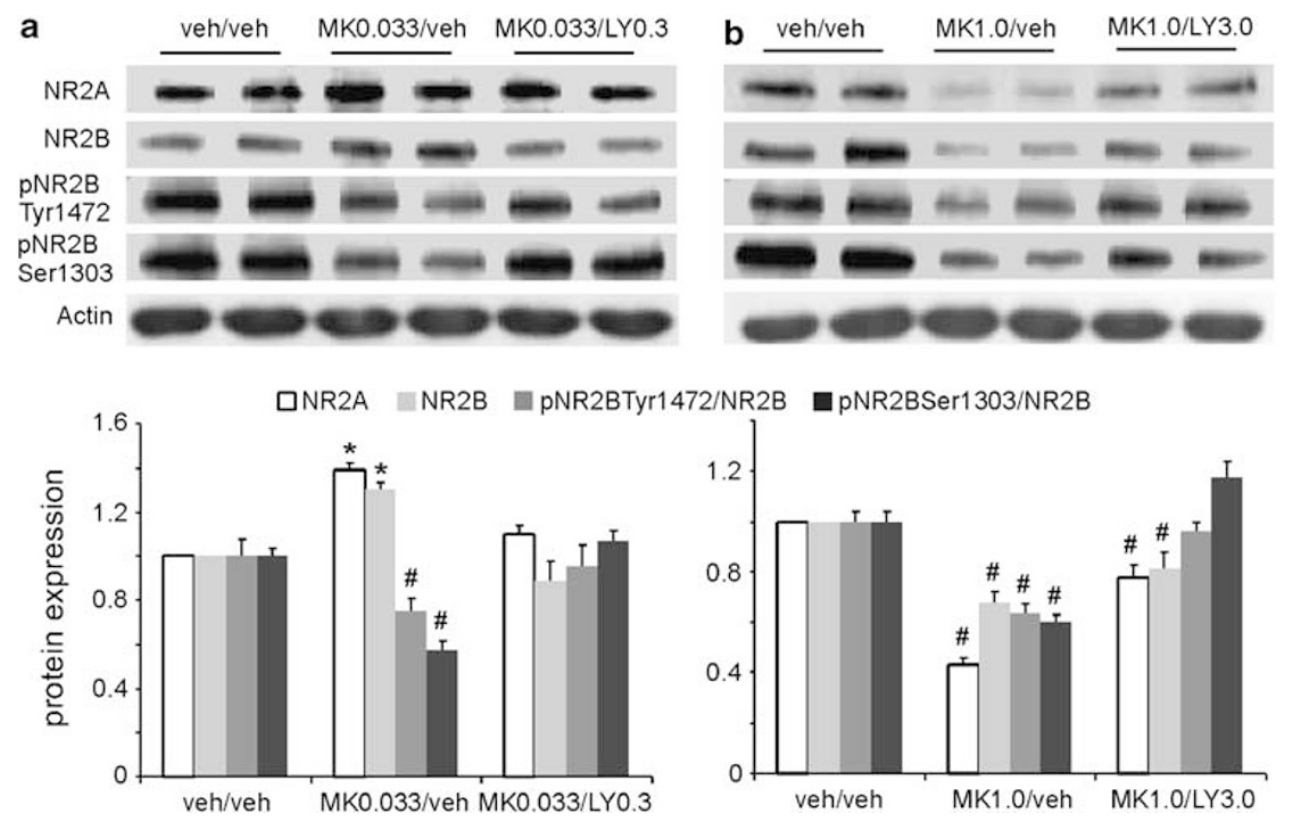

Figure I The mGluR2/3 agonist LY379268 recovered the disrupted expression of NMDA receptors induced by subchronic MK-80 I administration. The drugs were administered once a day for 5 days (i.p.). LY379268 was applied 50 min after MK-80I injection and brain tissues were collected for western blotting $50 \mathrm{~min}$ after the last injection. (a) Subchronic administration of MK-80 I at $0.033 \mathrm{mg} / \mathrm{kg}$ significantly increased the total proteins of NR2A and NR2B subunits and decreased NR2B phosphorylation at Serl 303 and Tyrl $472(P<0.05)$. LY379268 treatment $(0.3 \mathrm{mg} / \mathrm{kg})$ completely recovered the disrupted expression of NMDA receptors induced by MK-80I. Both total protein and NR2B phosphorylation were recovered to control levels $(P>0.05)$. (b) In contrast, MK-80 I at $1.0 \mathrm{mg} / \mathrm{kg}$ dramatically and significantly decreased the total proteins of NR2A and NR2B subunits, as well as phosphorylation of Ser I 303 and Tyrl $472(P<0.05)$. LY379268 treatment $(3 \mathrm{mg} / \mathrm{kg})$, however, only partially but significantly restored the total protein levels of NR2A and NR2B subunits $(P<0.05)$, although the phosphorylation was completely recovered to control levels. *increase, $P<0.05$; ${ }^{*}$ decrease, $P<0.05$.

treatment, relative to the animals' pre-drug baseline $(n=20$, $P<0.05)$. No other motor effects were observed in the animals (Supplementary Figure 1).

LY379268 at 0.3 or $3.0 \mathrm{mg} / \mathrm{kg}$ i.p., respectively, was administered $50 \mathrm{~min}$ after each injection of MK-801. We first examined the expression levels of NR2A and NR2B subunits in response to subchronic treatment with MK-801. Note that the expression levels of NR2A and NR2B were normalized to those of actin controls, whereas the expression levels of phospho-NR2B Tyr1472 and Ser1303 were normalized to the total protein level of NR2B. As shown in Figure 1, treatment with $0.033 \mathrm{mg} / \mathrm{kg}$ MK-801 significantly increased expression levels of NR2A and NR2B subunits $(P<0.05)$ without significant effect on the NR2A/NR2B ratio $(P>0.05)$. In contrast, at a high dose of $1 \mathrm{mg} / \mathrm{kg}$, MK801 induced significant decreases in the levels of both NR2A and NR2B proteins $(P<0.05)$ and in the NR2A/NR2B ratio $(P<0.05)$. These data indicate that low and high doses of MK-801 induce opposite changes in NMDA receptors in the PFC, consistent with the results of our recent study (Xi et al, 2009b). In addition, subchronic administration of MK-801 at both doses significantly decreased the ratios of pNR2B/ NR2B at Ser1303 and Tyr1472 $(P<0.05)$.

We found that low-dose treatment with LY379268 $(0.3 \mathrm{mg} / \mathrm{kg})$ led to complete recovery of the disrupted expression of NMDA receptors induced by low-dose MK801. Both total protein expression and NR2B phosphorylation were recovered to control levels $(P>0.05$, Figure 1a). In contrast, although treatment with LY379268 $(3 \mathrm{mg} / \mathrm{kg})$ completely restored the pNR2B/NR2B ratio at the phosphorylation sites of Ser1303 and Tyr1472, it only partially rescued the total proteins of NR2A and NR2B subunits induced by high-dose MK-801 (ANOVA, MK-801 at 0.033 $\mathrm{mg} / \mathrm{kg}$ and $\mathrm{LY}$ at $0.3 \mathrm{mg} / \mathrm{kg}$ : NR2A, $F=47.5, P<0.001$; NR2B $, \quad F=23.39, \quad P<0.001 ;$ pNR2BTyr1472, $F=25.91$, $P<0.001$; pNR2BSer1303, $F=46.98, P<0.001$. MK- 801 at $1.0 \mathrm{mg} / \mathrm{kg}$ and $\mathrm{LY}$ at $3.0 \mathrm{mg} / \mathrm{kg}$ : NR2A, $F=64.17, P<0.001$; NR2B $, F=13.58, P<0.001$; pNR2BTyr1472, $F=2.78, P=$ 0.085 ; pNR2BSer1303, $F=42.93, P<0.001$; Figure $1 \mathrm{~b}$ ). These data indicate that, as we proposed, the mGluR agonist can restore the disrupted NMDA receptor functions induced by subchronic MK-801 treatment by readjusting subunit expression and phosphorylation of NMDA receptors in the PFC.

\section{Acute Administration of Ly379268 Reverses the Disrupted NMDA Receptor Expression Induced by MK-801 Treatment}

To investigate the mechanisms associated with LY379268 in the modulation of NMDA receptors, we tested acute effects of MK-801 and LY379268 on the NR2A and NR2B expressions. As shown in Figure 2, a single low-dose injection of MK-801 $(0.033 \mathrm{mg} / \mathrm{kg}$, acute) induced a significant increase of NR2B subunit $(P<0.05)$ and a decrease of pNR2B Tyr1472 $(P<0.05)$, but had no effect on NR2A $(P>0.05)$. A single, low-dose injection of LY379268 $(0.3 \mathrm{mg} /$ $\mathrm{kg}$ ), either before or after MK-801 administration, partially reversed the MK-801 effects on NR2B and pNR2BTyr1472 expressions. In contrast, high-dose MK-801 ( $1 \mathrm{mg} / \mathrm{kg})$ administration significantly decreased the total protein levels of both NR2A and NR2B subunits, as well as pNR2BTyr1472 expression $(P<0.05)$. LY379268 $(3 \mathrm{mg} / \mathrm{kg})$, 

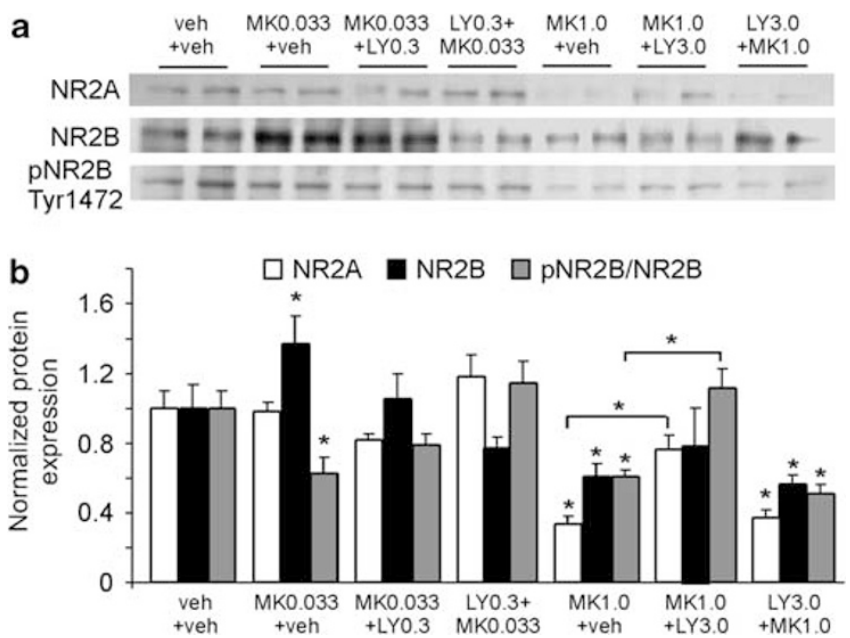

Figure 2 Acute administration of LY379268 reverses the NMDA receptor expression induced by MK-80 I treatment. (a) Representative western blot showing the expressions of NRI, NR2B, and pNR2BTyrl 472 under different treatment groups. (b) Summary histogram showing the comparisons of altered NR2A, NR2B, and pNR2BTyr I 472. Single low-dose MK-80 I $(0.033 \mathrm{mg} / \mathrm{kg}$, acute, i.p.) induced a significant increase of NR2B $(P<0.05)$ and a decrease of pNR2BTyrl $472(P<0.05)$, but had an effect on NR2A $(P>0.05)$. Acute LY379268 $(0.3 \mathrm{mg} / \mathrm{kg})$ treatment at low dose, either before or after MK-80 I administration, partially reversed the MK-80 I effects on NR2B and pNR2BTyrl 472 expressions. In contrast, high-dose MK-80 I ( $\mathrm{mg} / \mathrm{kg}$ ) significantly decreased both NR2A and NR2B, as well as pNR2BTyrl 472 expression ( $P<0.05)$. LY379268 $(3 \mathrm{mg} / \mathrm{kg})$, when applied $50 \mathrm{~min}$ after, but not $30 \mathrm{~min}$ before, MK-80I administration, partially reversed NR2A but not NR2B, and completely recovered pNR2BTyrl 472 to control level. $* P<0.05$.

when applied $50 \mathrm{~min}$ after, but not $30 \mathrm{~min}$ before, MK-801 administration, partially reversed NR2A but not NR2B expression, and completely recovered pNR2BTyr1472 to control levels (ANOVA, MK-801 at $0.033 \mathrm{mg} / \mathrm{kg}$ and LY at $0.3 \mathrm{mg} / \mathrm{kg}: \quad \mathrm{NR} 2 \mathrm{~A}, \quad F=2.95, \quad P>0.05 ; \quad \mathrm{NR} 2 \mathrm{~B}, \quad F=3.56$, $P<0.001$; pNR2BTyr1472, $F=5.42, P<0.005$. MK-801 at $1.0 \mathrm{mg} / \mathrm{kg}$ and $\mathrm{LY}$ at $3.0 \mathrm{mg} / \mathrm{kg}: \mathrm{NR} 2 \mathrm{~A}, F=19.70, P<0.001$; NR2B $, \quad F=2.16, \quad P=0.110 ; \quad$ pNR2BTyr1472, $\quad F=13.73$, $P<0.001)$. This data indicate that acute LY379268 is able to restore the disrupted NMDAR functions induced by acute MK-801 administration but may not prevent the effects of MK-801 at high dose.

Similar to Clozapine, the mGluR2/3 Agonist LY379268 Increases the Expression of NMDA Receptors in Normal Rat PFC

Several lines of evidence implicate an NMDA receptor hypofunction in the cognitive deficits of patients with schizophrenia, suggesting that pharmacological manipulation of NMDA receptors may be a feasible therapeutic strategy for treatment of this devastating disorder (Coyle et al, 2003; Farber et al, 1998; Millan, 2005; Moghaddam, 2003). Indeed, previous studies have indicated that functions of NMDA receptors are effectively regulated by D2 antipsychotic agents (Arvanov et al, 1997; Ninan et al, 2003; Wittmann et al, 2005). We therefore examined the effects of acute LY379268 (single-dose injection, i.p.) on NMDA receptor subunit expression and on NR2B phosphorylation
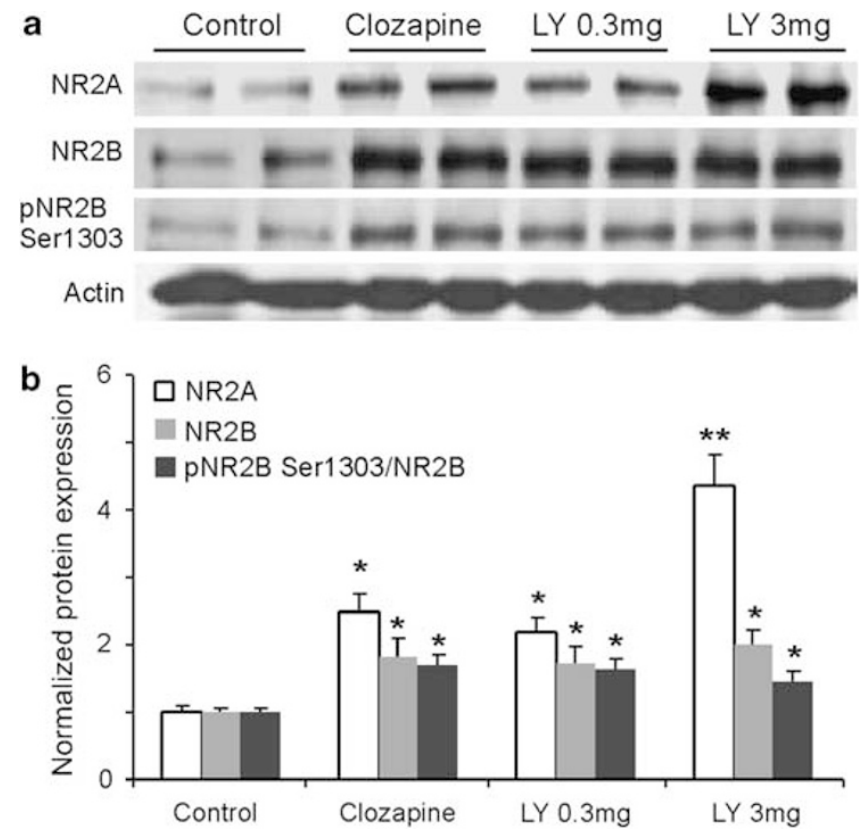

Figure 3 Similar to clozapine, acute treatment of the mGluR2/3 agonist LY379268 enhances NMDA receptor functions in normal rat PFC. (a) Representative western blot images of the expression of NR2A, NR2B, pNR2B Ser1303, and actin. (b) Summary histogram showing the similar and significant enhancing effects of clozapine $(5 \mathrm{mg} / \mathrm{kg}$, i.p.) and LY379268 on the expressions of NR2 subunits and PNR2B Serl303 $(P<0.05)$. Overall, it appeared that the increases in NR2A proteins were more than those in NR2B for all drug treatments $(P<0.05)$. The total protein level of NR2A was particularly upregulated by high-dose LY379268 $(3.0 \mathrm{mg} / \mathrm{kg})$ compared with that of low-dose LY379268 $(0.3 \mathrm{mg} / \mathrm{kg})$ and clozapine $(P<0.05)$. $* P<0.05$; $* * P<0.01$.

in the PFC compared with those of the D2 antipsychotic drug clozapine $(5 \mathrm{mg} / \mathrm{kg}$, i.p.). We found that, as shown in Figure 3, similar to the effects of clozapine, LY379268 significantly increased the expression of both NR2A and NR2B subunits as well as the phosphorylation of pNR2B Ser1303 in the PFC (ANOVA, NR2A, $F=21.10, P<0.001$; NR2B, $F=6.50, P<0.005 ;$ pNR2BSer1303, $F=6.59, P<$ $0.005)$. The representative western blot images and the summary histogram (Figure $3 \mathrm{a}$ and $\mathrm{b}$ ) showed the comparison of NR2A, NR2B, and pNR2B Ser1303 expressions between control and drug-treated groups. Overall, NR2A protein was increased to higher levels than NR2B for all drug treatments $(P<0.05)$. The total NR2A protein level was particularly upregulated by a high dose of LY379268 $(3.0 \mathrm{mg} / \mathrm{kg})$ compared with that of a low dose $(0.3 \mathrm{mg} / \mathrm{kg}, P<0.05)$. Our data support previous studies indicating that clozapine can directly regulate NMDA receptors (Arvanov et al, 1997; Ninan et al, 2003; Wittmann et al, 2005). Most importantly, the enhancing effects of LY379268 on NMDA receptors support our hypothesis and are in agreement with recent findings reported in vitro (Oliveira et al, 2008; Tyszkiewicz et al, 2004).

\section{The mGluR2/3 Agonist LY379268 Enhances NMDA-Mediated Current in Layer 5 Pyramidal Neurons}

To confirm the effects of the mGluR2/3 agonist on NMDA receptor function, we investigated the effects of LY379268 on NMDA-induced currents in PFC layer 5 pyramidal 

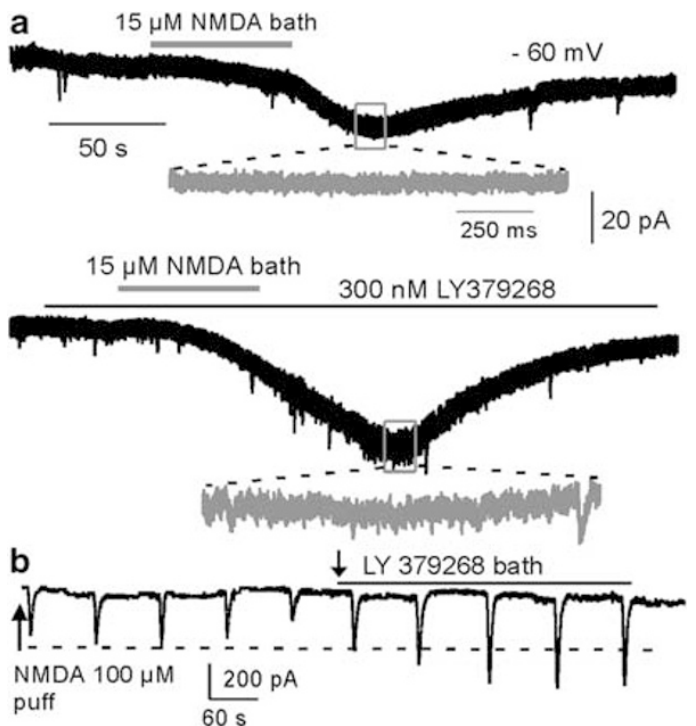

Figure 4 LY379268 enhances NMDA-mediated current. (a) Bathapplied NMDA ( $15 \mu \mathrm{M})$ induced stable inward current when recorded at $-60 \mathrm{mV}$ in the presence of CNQX $(20 \mu \mathrm{M})$ and picrotoxin $(50 \mu \mathrm{M})$ with regular Ringer's solution. Bath application of LY379268 (300 nM) dramatically and significantly increased the NMDA-induced current by an average of $48.6 \pm 14.7 \%(n=4, P<0.05)$. (b) Puff-NMDA-induced currents were also dramatically and significantly increased by LY379268 (300 nM bath) by $53.1 \pm 13.0 \%(n=5, P<0.0 \mid)$.

neurons. As shown in Figure 4a, bath-applied NMDA $(15 \mu \mathrm{M})$ induced stable inward current when recorded at $-60 \mathrm{mV}$ in the presence of AMPA receptor antagonist 6-cyano-7-nitroquinoxaline-2,3-dione (CNQX) $(20 \mu \mathrm{M})$ and GABAa receptor antagonist picrotoxin $(50 \mu \mathrm{M})$ with regular Ringer's solution. LY379268 (300 nM) dramatically and significantly increased the NMDA-induced current by an average of $48.6 \pm 14.7 \%(n=4, P<0.05)$. This enhancement was further verified in another set of experiments in which NMDA was applied through pressure puffs $(100 \mu \mathrm{M}$ puff, $0.2-0.3 \mathrm{~s}, 1-2 \mathrm{psi}$, every $90 \mathrm{~s})$. The puff-NMDA-induced currents were also dramatically and significantly increased by LY379268 (300 nM bath) for $53.1 \pm 13.0 \%(n=5, P<0.01$, Figure $4 \mathrm{~b}$ ), and this effect was long lasting with little recovery in washout. Again, the NMDA enhancement was consistent with results from previous studies conducted in dissociated prefrontal neurons (Tyszkiewicz et al, 2004) and in cortical slices under conditions of blocking glutamate transporters (Oliveira et al, 2008).

\section{The mGluR2/3 and NMDA Receptors are not Co-Localized in the PFC}

Our results provide strong evidence that mGluRs regulate NMDAR subunit expression, phosphorylation, and function. To examine how this occurs, we first tested whether the effects involve protein-protein interactions because previous studies indicated that mGluRs could potentially interact with other receptor proteins (Enz, 2007; GonzalezMaeso et al, 2008). As shown in Figure 5, the representative western blot images of co-immunoprecipitation showed that the immunoprecipitated protein of mGluR2/3 did not contain NR2B (Figure 5a), and the immunoprecipitated
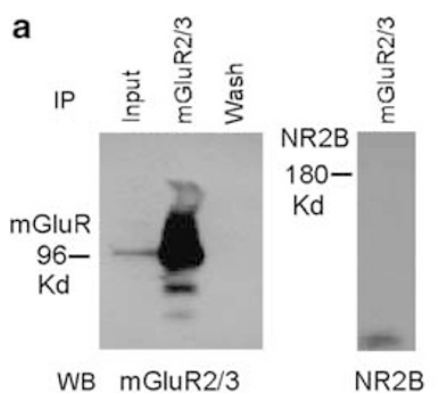

b

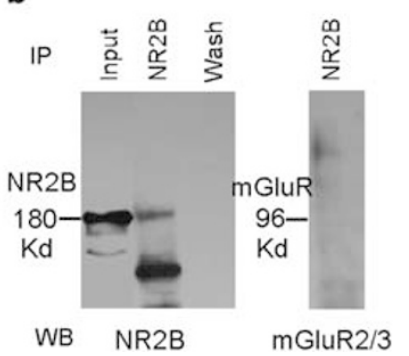

Figure 5 The $m$ GluR2/3 and NMDA receptors are not co-localized in the PFC. Both mGluR2/3 (a) $96 \mathrm{kD}$ ) and NR2B (b) $180 \mathrm{kD}$ ) were immunoprecipitated with anti-mGluR2/3 and anti-NR2B antibodies, respectively, and were confirmed by western bolt ( $\mathrm{a}, \mathrm{b}$; left panel). The immunoprecipitated mGluR2/3 proteins did not express NR2B (a; right panel) and immunoprecipitated NR2B proteins did not express mGluR 2/3 (b; right panel), confirming that co-localization is not found between these two receptors. The inputs represented the mGluR2/3 (a; left panel) or NR2B (b; left panel) signal. Wash denotes the negative control, which was treated with the wash-in supernatant of IP-mGluR2/3 (a; left panel) or IP-NR2B (b; left panel) after the immunoprecipitated samples were centrifuged.

protein of NR2B also did not contain mGluR2/3 (Figure 5b). As NR2B subunits usually form heteromer with NR2A and NR1 in the central nervous system (Cull-Candy and Leszkiewicz, 2004), these results suggest that direct proteinprotein interaction between these two receptors may not occur in the prefrontal neurons.

\section{The mGluR2/3 Agonist Ly397268 Shares a Common Signaling Pathway (Akt/Gsk Pathway) with Clozapine in the Normal Rat PFC}

How does the mGluR2/3 agonist affect the expression and function of NMDA receptors if not via direct proteinprotein interaction? As mGluR2/3 agonists share similar antipsychotic efficacy with D2 antipsychotic agents, we tested whether they share this same signaling pathway, as previously reported (Svenningsson et al, 2003), in the PFC by examining the acute effects of LY379268 on the Akt and GSK-3 $\beta$ signaling. To detect the phosphorylation of Akt and GSK-3 $\beta$, we injected the drugs intraperitoneally $60 \mathrm{~min}$ before anesthesia and decapitation for immunoblot analysis. Acute i.p. administration of LY379268 (0.3 and $3.0 \mathrm{mg} /$ $\mathrm{kg}$ ) or clozapine $(5 \mathrm{mg} / \mathrm{kg})$ similarly affects the expression of Akt and GSK-3 $\beta$ (Figure 6). The total protein levels of GSK-3 $\beta$ in all drug-treated groups were stable, without significant changes $(P>0.05$, Figure 6$)$. In contrast, LY379268 at 0.3 and $3.0 \mathrm{mg} / \mathrm{kg}$, and clozapine significantly increased the expression of GSK-3 $\beta$ Ser9 phosphorylation by $1.36,1.22,1.79$, and 1.50 fold, respectively $(P<0.05)$. Moreover, Akt, an upstream inhibitor of GSK3 $\beta$, was significantly increased by LY379268 at $3.0 \mathrm{mg} / \mathrm{kg}$ and by clozapine treatment $(P<0.05)$ but was not altered by LY379268 at $0.3 \mathrm{mg} / \mathrm{kg}$. The phosphorylation of pAkt Ser473, which would activate Akt, was, however, differentially and significantly changed by LY379268 at $0.3 \mathrm{mg} / \mathrm{kg}$ (increased almost 2-fold, $P=0.010$ ) and $3.0 \mathrm{mg} / \mathrm{kg}$ (decreased, $P=0.007)$, and decreased but not significantly by clozapine $(P=0.057)$. ANOVA analysis indicates significant changes of pGSK-3 $\beta$ Ser9, Akt and pAkt but not GSK-3 $\beta$ 

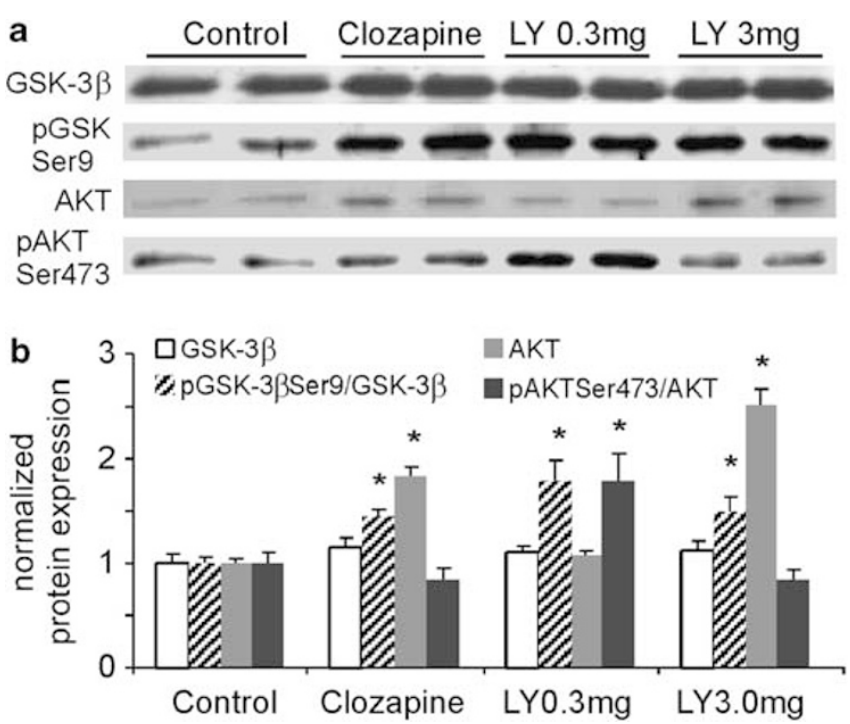

Figure 6 Clozapine shares a common signaling pathway (Akt/GSK pathway) with the mGluR2/3 agonist in normal rat PFC. Acute intraperitoneal administration of LY379268 (0.3 and $3.0 \mathrm{mg} / \mathrm{kg})$ or clozapine $(5 \mathrm{mg} / \mathrm{kg})$ similarly affects the expression of GSK-3 $\beta$ and Akt. $(a, b)$ The total protein levels of GSK-3 $\beta$ in all drug-treated groups were stable, without significant changes $(P>0.05)$. In contrast, clozapine and both doses of LY379268 significantly increased the expression of GSK-3 $\beta$ Ser9 phosphorylation $(P<0.05)$. Moreover, Akt was significantly increased in response to treatment with LY379268 $(3.0 \mathrm{mg} / \mathrm{kg})$ or clozapine $(P<0.05)$ but was not altered by treatment with LY379268 at $0.3 \mathrm{mg} / \mathrm{kg}$. The phosphorylation was, however, differentially and significantly changed by LY379268 at $0.3 \mathrm{mg} / \mathrm{kg}$ (increased almost twofold, $P=0.010$ ) and at $3.0 \mathrm{mg} / \mathrm{kg}$ (decreased, $P=0.007$ ) and decreased but not significantly by clozapine treatment $(P=0.057)$. ${ }^{*} P<0.05$.

(GSK-3 $\beta, \quad F=0.68, \quad P=0.574 ; \quad$ pGSK-3 $\beta$ Ser9,$\quad F=5.42$, $P<0.01$; Akt, $F=53.23, P<0.001 ;$ pAktSer473, $F=6.80$, $P<0.005)$. These results indicated that LY379268 and D2 antipsychotic agents similarly decreased GSK-3 $\beta$ activity by increasing pGSK-3 $\beta$ Ser9 and Akt or pAkt Ser473 expressions, consistent with those from previous studies (Emamian et al, 2004; Li et al, 2007).

\section{Regulation of Gsk-3 $\beta$ Activity Contributes to the Postsynaptic Effects of mGluR2/3 Agonist LY379268 on Disrupted NMDA Receptors Induced by MK-801}

Previous studies indicated that phosphorylation of molecules associated with the GSK-3 $\beta$ signaling pathway in rat brain was dose dependently altered by injection with PCP/ MK-801 (Ahn et al, 2005; Seo et al, 2007), with significant alterations of pAktSer473 and pGSK-3 $\beta$ Ser9 levels. These changes peaked at $30 \mathrm{~min}$ and remained steady until $90 \mathrm{~min}$ after injection. The question is whether treatment with LY379268 could restore the altered-Akt-GSK-3 $\beta$ signaling induced by acute and subchronic MK-801 injection in vivo. As shown in Figure 7, acute MK-801 at a low dose $(0.033 \mathrm{mg} / \mathrm{kg})$ induced negligible effects on total protein levels of GSK-3 $\beta$ and Akt $(P>0.05)$ and of pGSK-3 $\beta$ Ser9 $(P>0.05)$ but led to a significant decrease of protein levels of pAkt Ser473 $(P<0.05)$, indicating a possible increase in GSK-3 $\beta$ activity. Treatment with LY379268 rescued the pAkt Ser473 to vehicle control levels. In contrast, high-dose MK$801(1 \mathrm{mg} / \mathrm{kg})$ significantly decreased the total proteins of
GSK-3 $\beta$ and Akt $(P<0.05)$ as well as the ratios of pGSK-3 $\beta$ Ser9/GSK-3 $\beta$ and pAkt Ser473/Akt $(P<0.05)$ (Figure $7 \mathrm{a}$ and b); these results agree with those of Lei et al (Lei et al, 2008) and differ slightly from those of other researchers (Ahn et al, 2005; De Sarno et al, 2006; Seo et al, 2007). LY379268 treatment partially but significantly reversed the alterations of Akt and pAkt Ser473 induced by MK-801 when it (LY379268) was applied after but not before MK-801. It did, however, completely recover the expressions of GSK-3 $\beta$ and pGSK-3 $\beta$ Ser9 (ANOVA, MK-801 of $0.033 \mathrm{mg}$ and LY of $0.3 \mathrm{mg} / \mathrm{kg}: \quad \mathrm{GSK}-3 \beta, \quad F=0.94, \quad P=0.432$; $\quad$ GGSK-3 $\beta$ Ser9, $F=0.46, P=0.712$; Akt, $F=0.32, P=0.812$; pAktSer473, $F=3.72, P=0.028$. MK- 801 of $1 \mathrm{mg}$ and $\mathrm{LY}$ of $3 \mathrm{mg} / \mathrm{kg}$ : GSK-3 $\beta, \quad F=3.18, \quad P=0.036 ; \quad$ pGSK-3 $\beta$ Ser9,$\quad F=9.16$, $P<0.001$; Akt, $F=27.63, \quad P<0.001$; $\quad$ AAktSer473, $F=4.29, \quad P=0.017)$. These data suggest that LY379268 reversed the effects of MK- 801 by modulating the Akt/GSK$3 \beta$ pathway.

We next examined the effects of MK-801 and LY379268 on the Akt/GSK-3 $\beta$ pathway under conditions of subchronic treatments to see whether LY379268 could also recover subchronic MK-801-induced disruption of NMDA receptors in the PFC via this signaling pathway. As shown in Figure $7 c$, the upper panel represents the immunoblots of GSK-3 $\beta$ and pGSK-3 $\beta$ Ser9 in control, MK-801-treated, and MK-801/LY379268-treated groups, whereas the lower panel shows the summary data. MK-801 at $0.033 \mathrm{mg} / \mathrm{kg}$ significantly decreased the protein of pGSK-3 $\beta$ Ser9 $(P<0.05)$ but not the total protein of GSK-3 $\beta(P>0.05)$; this decrease was reversed by LY379268 at $0.3 \mathrm{mg} / \mathrm{kg}(P>0.05)$. In contrast, both GSK-3 $\beta$ and pGSK-3 $\beta$ Ser9 were significantly decreased by subchronic MK-801 at $1.0 \mathrm{mg} / \mathrm{kg}(P<0.05)$, and LY379268 at $3.0 \mathrm{mg} / \mathrm{kg}$ restored the pGSK-3 $\beta$ Ser9 level $(P>0.05)$ but had little effect on total GSK-3 $\beta$ expression $(P<0.05$, ANOVA analysis of MK-801 at $0.033 \mathrm{mg}$ and LY at $0.3 \mathrm{mg} / \mathrm{kg}$ : GSK-3 $\beta, \quad F=1.09, \quad P=0.350$; $\mathrm{pGSK}-3 \beta$ Ser9, $F=11.83, P<0.001$. MK-801 at $1 \mathrm{mg}$ and LY at $3 \mathrm{mg} / \mathrm{kg}$ : GSK-3 $\beta, \quad F=2.24, \quad P=0.135 ; \quad$ pGSK-3 $\beta$ Ser9, $\quad F=9.13$, $P<0.005$. Figure $7 \mathrm{c}$ ), suggesting a complex action.

Intermediate Dose of LY379268 Reversed the Effects of Medium-Dose MK-801 on Both NMDA Receptors and GSK-3 $\beta$ Activity

Because of the complicated actions of low and high doses of LY379268 on the effects of low $(0.033 \mathrm{mg} / \mathrm{kg})$ and high $(1.0 \mathrm{mg} / \mathrm{kg})$ doses of Mk-801-induced expression of GSK-3 $\beta$ activity, we tested the effects of an intermediate dose of LY379268 $(1.0 \mathrm{mg} / \mathrm{kg})$ on medium-dose $(0.1 \mathrm{mg} / \mathrm{kg}$, single dose) MK-801-induced expression of NR2 subunits and the Akt/GSK-3 $\beta$ pathway. As exhibited in Figure 8, LY379268 also recovered the MK-801 effects on the expressions of both the NR2A subunit and Akt/GSK-3 $\beta$ activity. The medium dose of $\mathrm{MK}-801$ induced a significant increase of NR2A $(P<0.05)$, but not NR2B subunit $(P>0.05)$ levels and an intermediate dose of LY379268 recovered the NR2A expression, without a clear effect on NR2B (ANOVA, NR2A, $F=3.33, P=0.045$; NR2B, $F=1.44, P=0.26$ ). In addition, the medium dose of MK-801 induced significant decreases of both pGSK-3 $\beta / \mathrm{GSK}-3 \beta$ and $\mathrm{pAkt} / \mathrm{Akt}$ ratios $(P<0.05)$, but had no significant effects on the total protein levels of GSK-3 $\beta$ and Akt $(P>0.05)$. Further, the medium dose of 
a

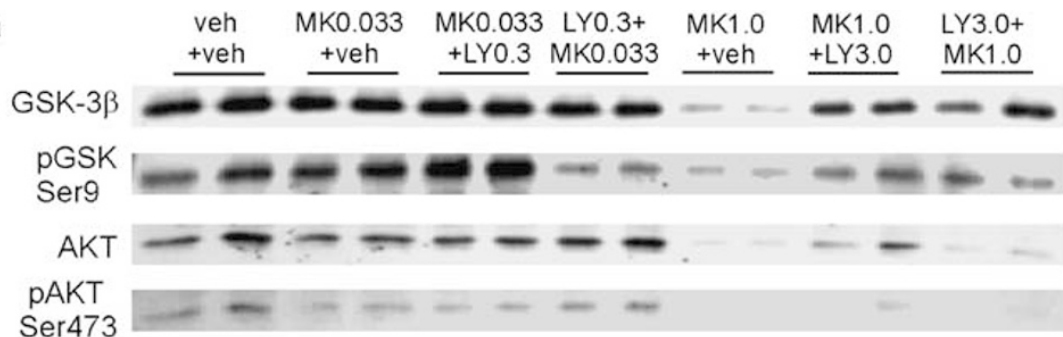

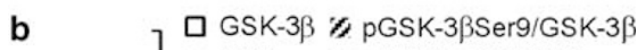

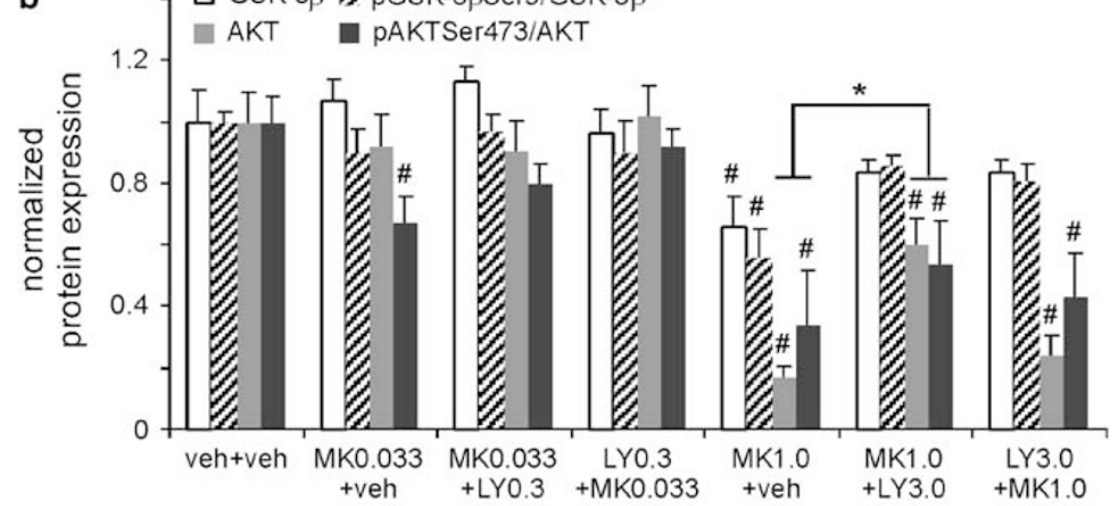

c

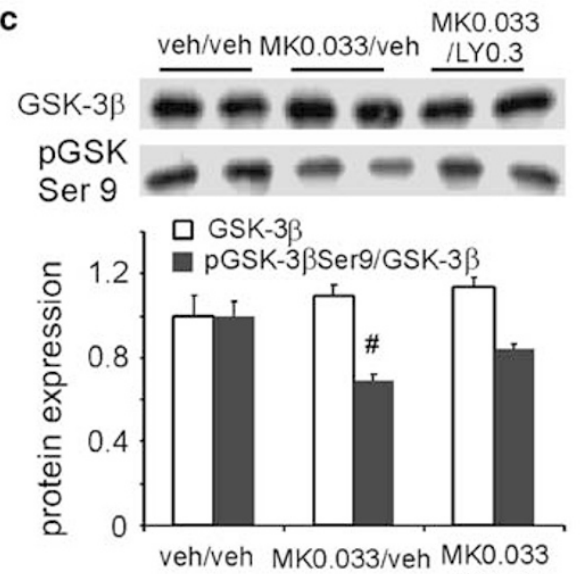

MK1.0

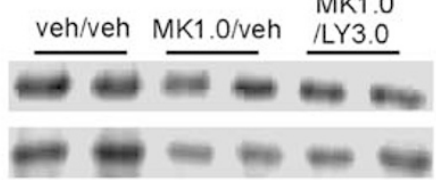

/LY0.3

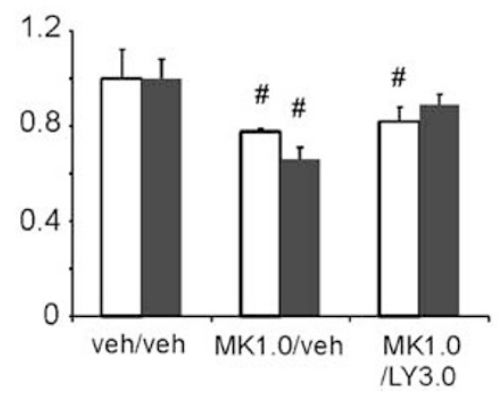

Figure 7 Activation of the Akt/GSK pathway contributes to the postsynaptic effects of the mGluR2/3 agonists. (a, b) Immunoblots and summary histogram show the expressions of GSK-3 $\beta$, pGSK3 $\beta$ Ser9, Akt, and pAktSer473 in control and six acute treated groups. Acute MK-80I at low dose $(0.033 \mathrm{mg} / \mathrm{kg})$ induced negligible effects on total protein levels of GSK-3 $\beta$ and $(P>0.05)$ and of pGSK-3 $\beta$ Ser9 $(P>0.05)$, but induced a significant decrease of pAkt Ser473 $(P<0.05)$, indicating a possible increase of GSK-3 $\beta$ activity. LY379268 rescued the ratio of pAkt Ser473/Akt to vehicle control levels. In contrast, high-dose MK-80 I ( I mg/kg) significantly decreased the total proteins of GSK-3 $\beta$ and Akt $(P<0.05)$, as well as the ratios of pGSK-3 $\beta$ Ser9/GSK-3 $\beta$ and pAkt Ser473/Akt $(P<0.05)$. LY379268 treatment partially but significantly reversed the alterations of Akt and pAkt Ser473/Akt $(P<0.05)$ when it was applied after but not before MK-80 I administration. The expressions of GSK-3 $\beta$ and pGSK-3 $\beta$ Ser $9 /$ GSK-3 $\beta$ were, however, similarly recovered by treatment with LY379268. (c) Subchronic MK-80I at $0.033 \mathrm{mg} / \mathrm{kg}$ significantly decreased pGSK Ser9 $(P<0.05)$, but not total protein of GSK-3 $\beta$ $(P>0.05)$, and this decrease was reversed by LY379268 at $0.3 \mathrm{mg} / \mathrm{kg}(P>0.05)$. In contrast, both GSK-3 $\beta$ and pGSK Ser9 were significantly decreased by subchronic MK-80 I at $1.0 \mathrm{mg} / \mathrm{kg}(P<0.05)$, and LY379268 at $3.0 \mathrm{mg} / \mathrm{kg}$ restored pGSK-3 $\beta$ Ser9 levels $(P>0.05)$ but had minimal effects on total GSK-3 $\beta$ expression $(P<0.05)$. *increase, $P<0.05$; ${ }^{\#}$ decrease, $P<0.05$.

LY379268 reversed the pGSK-3 $\beta /$ GSK-3 $\beta$ and pAkt/Akt ratios and exhibited no effects on the total protein expressions of GSK-3 $\beta$ and Akt (ANOVA, GSK-3 $\beta$, $F=2.87, P=0.080$; pGSK-3 $\beta$ Ser9, $F=8.93, P=0.003$; Akt, $F=0.67,2.87, P=0.537$; pAktSer473, $F=7.71, P=0.004$ ). These data indicate that although a higher dose of MK-801 might mimic the psychosis of schizophrenia, its action on the NMDA receptors and Akt/GSK-3 $\beta$ pathway is more complicated.
Pre-Treatment with GSK-3 $\beta$ Inhibitor Blocks the Effects of LY379268 and Mk-801 on the Expression and Function of NMDA Receptors

If GSK-3 $\beta$ is a critical intracellular mediator in the regulation of NMDA receptor expressions in MK-801 and LY379268 treatment, inhibition of GSK- $3 \beta$ should block the effects of these drugs. We therefore examined the expression and phosphorylation of NMDA receptors under 
a
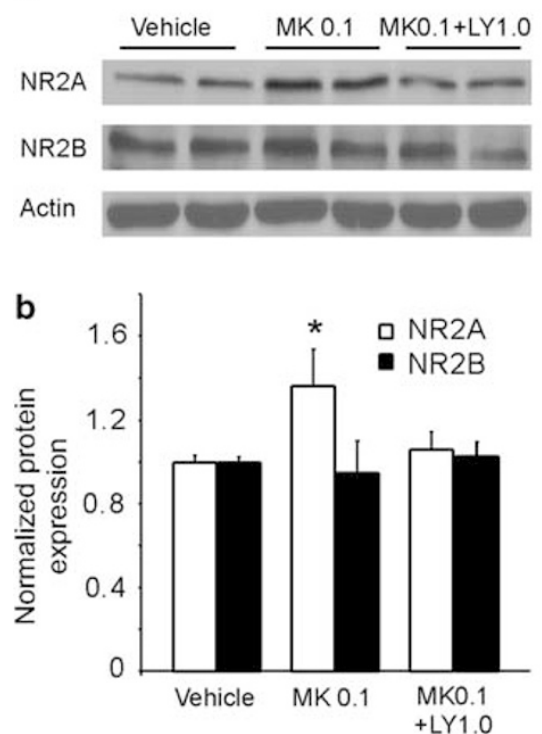

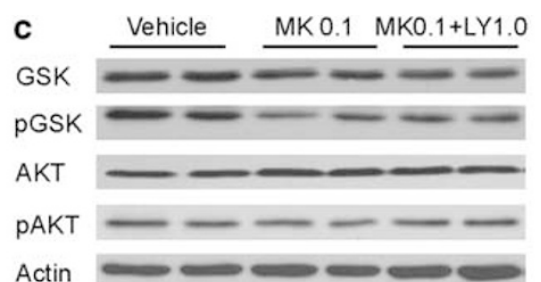

d

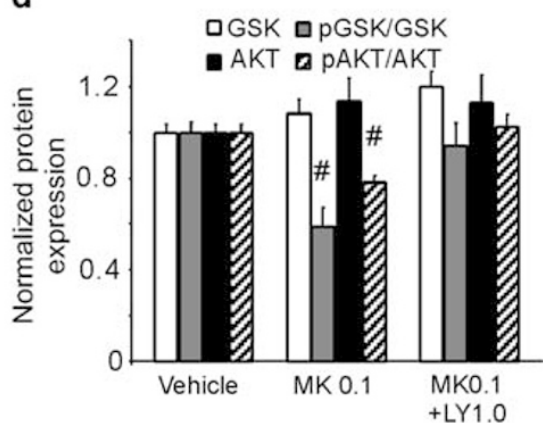

Figure 8 LY379268 also recovered the acute MK-80I effects on the expressions of both NR2A subunit and Akt/GSK-3 $\beta$ activity at medium dose. ( $a$ and b) Medium dose of MK-80I $(0.1 \mathrm{mg} / \mathrm{kg}$, single dose) induced significant increase of NR2A $(P<0.05)$, but not NR2B subunit and intermediate dose of LY379268 (I.0 mg/kg) recovered the NR2A expression without a clear effect on NR2B. (c and d) Medium dose of MK-80I induced significant decreases of both pGSKJGSK and pAkt/Akt ratios $(P<0.05)$ but had no clear effects on the total protein levels of GSK-3 $\beta$ and Akt. Medium dose of LY379268 reversed the pGSK/GSK and pAkt/Akt ratios and exhibited no effects on the total protein expressions of GSK-3 $\beta$ and Akt. *increase, $P<0.05$; ${ }^{\#}$ decrease, $P<0.05$

conditions of applying the potent, selective GSK-3 $\beta$ inhibitor SB216763 (3-(2,4-dichlorophenyl)-4-(1-methyl$1 \mathrm{H}$-indol-3yl)-1H-pyrrole-2,5-dione) (1 mg/kg, i.p.) $30 \mathrm{~min}$ before MK-801 or LY379268 injection. This dose was previously reported to be effective in protecting both small intestine epithelium and hippocampal neurons in vivo from radiation-induced apoptosis and can stabilize $\beta$-catenin, the downstream substrate of GSK-3 $\beta$ (Thotala et al, 2008, 2010). As shown in Figure 9a and b, an acute high dose of MK-801 $(1.0 \mathrm{mg} / \mathrm{kg})$ dramatically and significantly decreased the expressions of NR1, NR2A, NR2B, and pNR2B Ser1303 to almost undetectable levels $(P<0.01)$, whereas LY379268 $(3.0 \mathrm{mg} / \mathrm{kg})$ significantly increased the expressions and phosphorylation of NR2B, as well as NR1 and NR2A $(P<0.05, \quad$ ANOVA, NR1, $F=18.47, \quad P<0.001 ; \quad$ NR2A, $F=13.56, \quad P<0.001 ;$ NR2B $, F=23.02, \quad P<0.001 ;$ pNR2B Ser1303, $F=76.62, P<0.001)$. Pre-administration of the GSK-3 $\beta$ inhibitor SB216763 successfully blocked the effects of both MK-801 and LY37926 on the expression of NMDA receptor subunits and pNR2B Ser1303 $(P>0.05)$. To further confirm the effects of the GSK- $3 \beta$ inhibitor, we used another highly selective but structurally different GSK- $3 \beta$ inhibitor 4-benzyl-2-methyl-1,2,4-thiadiazolidine-3,5-dione (TDZD, $10 \mu \mathrm{M}$ ) to examine the role of LY379268 in NMDA-induced current in layer 5 prefrontal pyramidal neurons. We recently showed that both inhibitors have similar efficacy in hyperdopamine and D2 receptor-mediated action in NMDA receptor internalization ( $\mathrm{Li}$ et al, 2009), as previously reported in cultured cortical neurons (Chen et al, 2007b). In addition, we found that both GSK inhibitors themselves did not show clear effects on the basal NMDA receptor-mediated transmissions (Li et al, 2009). Similar findings were also reported in other studies (Peineau et al, 2007, 2008; Zhu et al, 2007). The amplitudes of puff-NMDA-induced currents (100 $\mu \mathrm{M}$ puff, $0.2-0.3 \mathrm{~s}, 1-2$ psi, every $90 \mathrm{~s}$ ) were significantly increased by about $50 \%$ in bath-applied LY379268 (300 nM, Figure 9c, left panel and right histogram), and in some cases, spikes were induced due to enhanced NMDA functions. The GSK- $3 \beta$ inhibitor TDZD itself did not show significant effects on the puffNMDA-induced currents (data not shown) but was effective in occluding the action of LY379268 when it was applied before LY379268 or co-applied with LY379268 (Figure 4 and Figure 9c, middle panel). The average amplitude of NMDA-induced currents in TDZD was almost identical to that in TDZD + LY379268 $(0.17 \pm 0.06 \%, P>0.05$, Figure $9 \mathrm{c}$ right histogram), suggesting the clear involvement of the Akt/GSK-3 $\beta$ pathway in the regulation of the NMDA receptor function.

\section{DISCUSSION}

In this study, we utilized the MK-801 model and investigated the antipsychotic effects of the mGluR2/3 agonist LY379268 on NMDAR functions in adult rat PFC.

There are several important findings (see Supplementary Table 1). First, we found that MK-801 induced distinct changes of NMDA receptor subunits under both conditions of acute and subchronic treatment. Both the NR2A and NR2B subunits, and particularly NR2A, were significantly increased by low-dose MK- 801 but decreased by high-dose treatment. This result was consistent with our recent report of an inverted-U dose dependent alteration of NR2 subunits in response to MK-801 administration (Xi et al, 2009b). In addition, both pNR2B Tyr1472 and Ser1303 were significantly decreased by MK-801. Most importantly, LY379268 effectively and bi-directionally recovered the disrupted 
a
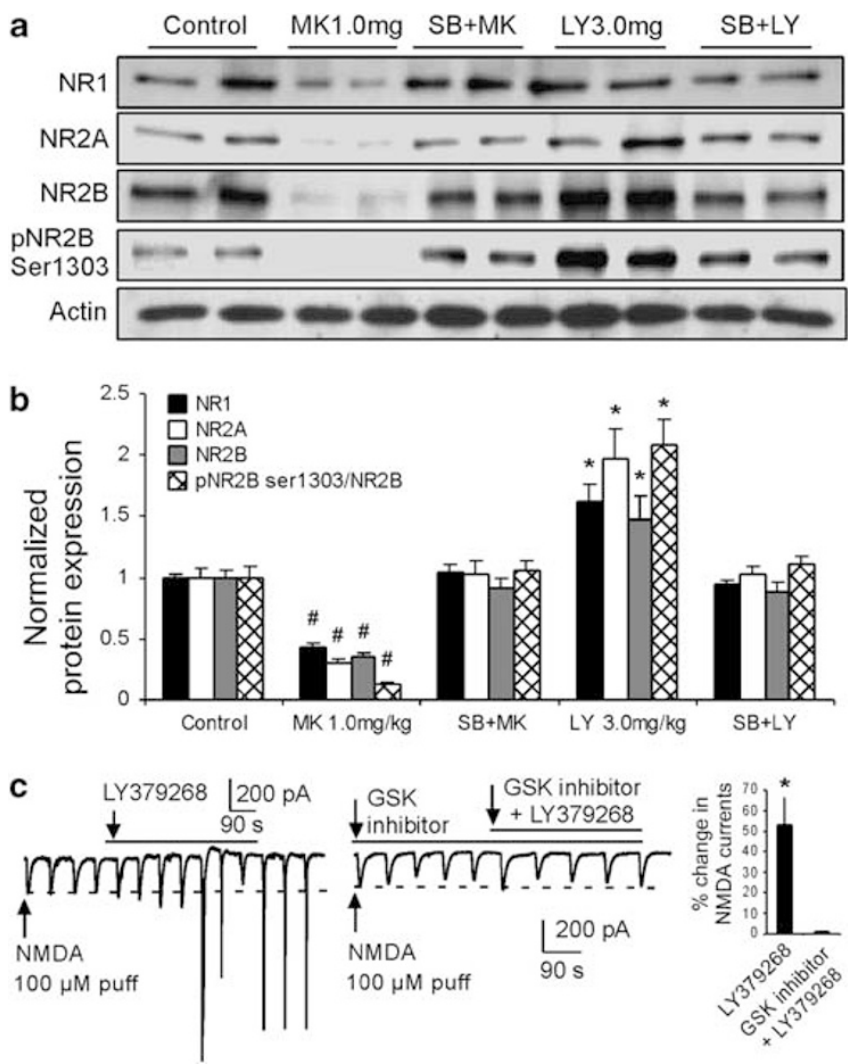

Figure 9 Effects of $\mathrm{mGluR2} / 3$ agonists on NMDA receptors are blocked by GSK inhibitor. (a, b) High-dose MK-80I (I.0 mg/kg, single dose) dramatically and significantly decreased the expression of NRI, NR2A, NR2B, and pNR2B Serl303 to almost undetectable levels $(P<0.0 \mathrm{I})$, whereas LY379268 $(3.0 \mathrm{mg} / \mathrm{kg}$, single dose) significantly increased the expression and phosphorylation of NR2B, NRI, and NR2A $(P<0.05)$. Pre-administration of the GSK-3 $\beta$ inhibitor SB2 16763 (I mg/kg, i.p., $30 \mathrm{~min}$ before MK-80 I or LY379268) successfully blocked the effects of both MK-80I and LY37926 on the expression of NMDA receptor subunits and pNR2B Serl 303 ( $P>0.05)$. (c) Left panel, puff-NMDA-induced currents ( $100 \mu \mathrm{M}$ puff, $0.2-0.3 \mathrm{~s}, \mathrm{I}-2 \mathrm{psi}$, every $90 \mathrm{~s}$ ) were significantly increased by LY379-268 (300 nM bath) and in some cases, spikes were induced by the enhanced NMDA current. Middle panel, selective GSK-3 $\beta$ inhibitor TDZD ( $10 \mu \mathrm{M}$ bath) itself did not show significant effects on the puff-NMDAinduced currents but was very effective in occluding the action of LY379268 (300 nM bath) when it was applied before LY379268 or co-applied with LY379268. Right panel: summary histogram showing that the NMDA current was significantly increased by about $50 \%$ in LY379268 $(* P<0.05)$ whereas the average amplitude of NMDA-induced currents in TDZD was almost identical to that in TDZD + LY379268 (0.17 \pm 0.06 , $\left.{ }^{\#} P>0.05\right)$.

expression of NMDA receptors induced by MK-801 administration, and this effect was attributable to the direct regulatory action of LY379268 on NMDA receptors via postsynaptic GSK-3 $\beta$ signaling pathway. These results provide useful insights into the mechanistic actions of mGluR2/3 agonists as potential antipsychotic agents for treating schizophrenia.

It is generally proposed that hypofunction of NMDA receptors on GABAergic interneurons disrupts the functional integrity of the corticolimbic circuit, which in turn results in disinhibition of glutamatergic pyramidal neurons and increased glutamate release (Lisman et al, 2008; Olney and Farber, 1995). Furthermore, numerous studies have reported changes in the expression of NR1, NR2A, and NR2B in the animal models of NMDA antagonists (Barbon et al, 2007; Gao and Tamminga, 1995; Harris et al, 2003; Lindahl and Keifer, 2004; Rujescu et al, 2006; Wang et al, 1999). There is, however, little consensus on what alterations in NMDA receptor subunits might contribute to the NMDA hypofunction observed in patients with schizophrenia, and some of these data are inconsistent (Akbarian et al, 1996; Kristiansen et al, 2007, 2010; Luthi et al, 2001; Matthews et al, 2000; Meador-Woodruff and Healy, 2000; Moghaddam, 2003). How do the disrupted expressions of NR2A and NR2B subunits, as well as the alteration of phosphorylation, affect brain functions and thus schizophrenia symptoms? NR2A and NR2B are the principal NR2 subunits in neurons of the PFC (Wang et al, 2008) and NR2A and NR2B subunits are differentially distributed on pyramidal neurons and GABAergic interneurons (Wang and Gao, 2009). Furthermore, NR2A- and NR2B-containing receptors also have different roles in synaptic modulation (Barria and Malinow, 2005). NR2B overexpression in the frontal cortex enhances cognitive functions (Tang et al, 1999); whereas mice lacking the NR2A subunit (Itokawa et al, 2003) or rats reared in isolation with increased NR2A expression in the PFC (Turnock-Jones et al, 2009) display abnormal behaviors, similar to schizophrenic symptoms. Indeed, we found that MK-801 administration induced significant changes of both NR2A and NR2B subunits in the PFC. NMDA receptor blockade has been found to reduce the number of parvalbumin (PV)-containing neurons and disruption in gamma rhythms in the entorhinal cortex (Cunningham et al, 2006). Interestingly, these effects may be mediated primarily by NR2A subunit because NR2A is particularly enriched in PV-containing GABA cells at both transcript and protein levels, as we reported (Wang and Gao 2009; Xi et al, 2009a b). As PV-containing GABA cells are selectively reduced in schizophrenia (Hashimoto et al, 2003), it is likely that alterations of NR2 subunits, particularly NR2A, may dramatically change the functions of inhibitory circuitry, as proposed in the NMDA hypofunction hypothesis. Indeed, a recent study suggests that the activity of NR2A-containing NMDA receptors has a pivotal role in the maintenance of the GABAergic function in PVcontaining interneurons (Kinney et al, 2006). The alteration of NR2A and NR2B subunits induced by MK-801, as observed in this study, could thus change the balance of neuronal activity between pyramidal neurons and GABAergic interneurons, and consequently affect brain functions.

The molecular mechanisms underlying the functional regulation of NMDA receptors have been the subject of extensive studies. In particular, phosphorylation has emerged as a fundamental mechanism that regulates NMDA receptor trafficking and channel properties (Chen and Roche, 2007a), and consequently, results in schizophrenia (Lau and Zukin, 2007). It follows then, that alterations in NMDAR phosphorylation states could have an important role in NMDAR hypofunction and the pathophysiology of schizophrenia. We found that both phosphorylation sites of NR2B Tyr1472 and Ser1303 were significantly decreased by MK-801. Although D2R-NR2B interaction was found to reduce NR2B phosphorylation at Ser1303 and to inhibit NMDA currents in the striatal neurons (Liu et al, 2006), it is unlikely that the change of pNR2BSer1303 observed in our 
study is mediated by D2 receptors because previous study indicated that mGluR2/3 did not interact with $\mathrm{D} 2$ receptors in both in vivo and in vitro (Fell et al, 2009). Nevertheless, the decrease of phosphorylations of Tyr1472 and Ser1303 in NR2B subunits in the MK-801 model may suggest a reduction of NR2B trafficking or dynamic although how the simultaneous decrease of these two phosphorylation sites affects the brain functions remains to be explored.

A clear picture of how NMDAR expression is disrupted in schizophrenia has not emerged and thus we cannot directly compare our current data. Still, the present observation of altered NR2 subunit expression in the PFC is suggestive of NMDA receptor dysfunction in a brain region involved in cognitive functions and therefore provides indirect support for the validity of NMDAR antagonism as a preclinical model of schizophrenia. Our data strongly suggest that alternation of NR2 subunits in the corticolimbic region have a critical role in the regulation of normal cortical functions as well as schizophrenic behaviors. We believe that, as previously reported (Jackson et al, 2004), a low-dose MK-801-induced increase of NR2A and NR2B would result in dysfunctions of cognitive functions, whereas decreased NR2 subunits in high dose of MK-801 would induce positive symptoms, as NR2A subunit is significantly decreased in brain tissues in patients with schizophrenia (Woo et al, 2004). These studies have thus provided strong evidence for the network effects of NMDA antagonism and established the theoretical basis for the NMDA hypofunction hypothesis for schizophrenia pathogenesis (Lisman et al, 2008).

An intriguing question that we explored is whether mGluR2/3 agonist can reverse disrupted NMDA receptor expressions in the MK-801 model. In our view, any antipsychotic agents used to treat schizophrenia should improve the functionality of NMDA receptors if NMDA hypofunction is critical for schizophrenia. We sought to determine whether and how mGluR2/3 agonists could improve the functions of the NMDA receptors. Many researchers speculate that mGluR2/3 agonists block NMDA antagonist-mediated behavior by reducing excessive glutamate release through presynaptic mechanisms (Moghaddam, 2004; Patil et al, 2007; Recasens et al, 2007; Schoepp, 2001), but how could a presynaptic inhibitor improve the function of NMDA receptors disrupted by non-competitive antagonists? The mGluR2/3 receptors are localized not only in presynaptic terminals but also in postsynaptic sites and glia in the cerebral cortex and limbic regions (Blumcke et al, 1996; Cartmell and Schoepp, 2000b; Liu et al, 1998; Moghaddam, 2004; Petralia et al, 1996a,b). The highly speculative role of the mGluR $2 / 3$ agonist in reducing presynaptic glutamate release ignores the possible modulatory effects of mGluR agonists in postsynaptic sites for both excitatory and inhibitory transmissions. In addition, mGluR2/3 agonists are also effective in attenuating amphetamine-induced hyperlocomotion (Cartmell et al, 1999) and LSD- or hallucinogenic drug-induced symptoms (GonzalezMaeso et al, 2008; Winter et al, 2004). The ability of mGluR2/3 agonists to reverse behaviors across psychostimulants and psychomimetics is an interesting feature that strongly suggests a mechanistic commonality between D2 antipsychotic drugs and mGluR2/3 agonists.

Indeed, we found that the mGluR2/3 agonist LY379268 was able to effectively and bi-directionally reverse the disrupted subunit expressions of NMDA receptor subunits induced by both low and high dose of MK- 801 administration. Interestingly, the total protein level of NR2A was also particularly upregulated by LY379268. An important issue is determining how LY379268 regulates NMDA receptors, by pre or postsynaptic mechanisms. Our data strongly suggest that the effects of mGluR2/3 agonist on NMDA receptor regulations are likely attributable to a direct postsynaptic action because (1) the NMDA-induced currents, which do not require presynaptic glutamate release, were significantly enhanced by mGluR2/3 agonist; (2) the large amount of protein expressions and phosphorylations in response to LY379268 treatment also indicated a direct postsynaptic modulation of NMDA receptor function; 3) the LY effects were effectively blocked by GSK- $3 \beta$ inhibitors under both in vitro and in vivo conditions.

How is this effect achieved and how is the NMDA receptor function regulated by mGluR2/3 agonist? The mGluR2/3 agonists are highly selective, without significant affinity for any other receptors, including dopamine receptors and ionotropic glutamate receptors (Chartoff et al, 2005; Fell et al, 2009; Harrison, 2008; Patil et al, 2007; Swanson and Schoepp, 2002). We also did not find a direct protein interaction between NR2 and mGluR2/3. Thus, it seems likely that mGluR $2 / 3$ agonists function through an intracellular signaling pathway to reverse MK801-induced disruption of NMDARs. However, despite compelling behavioral data and results from a recent preclinical trial (Patil et al, 2007), the cellular mechanisms by which activation of mGluR2/3 attenuates the effects of NMDA receptor antagonism remained an open question.

A likely candidate pathway, which we investigated, is the GSK3/AKT pathway. Several lines of evidence converge in implicating abnormal Akt and GSK-3 $\beta$ activity in the pathogenesis of schizophrenia (Arguello and Gogos, 2008; Emamian et al, 2004; Koros and Dorner-Ciossek, 2007; Tan et al, 2008). Changes in GSK-3 $\beta$ and Akt have also been identified in several animal models that mimic some of the symptoms of schizophrenia, including the ventral hippocampal lesion model and the dopamine transporter knockout mouse, and following challenge with psychotomimetic, amphetamine, and LSD (Ahn et al, 2005; Nadri et al, 2003; Svenningsson et al, 2003). Collectively, these studies suggest that the Akt/GSK-3 $\beta$ pathway may have a prominent role in schizophrenia and that antipsychotic agents may alleviate psychosis by directly reversing deficits through the cellular functions associated with GSK-3 $\beta$. As mGluR2/3 agonists and D2-related antipsychotic agents have similar therapeutic efficacies in reducing behavioral alterations in patients with schizophrenia and in animal models (Patil et al, 2007), we hypothesize that mGluR2/3 agonists and D2-related antipsychotic agents may share the same intracellular signaling pathway, ie, Akt/GSK-3 $\beta$, in the regulation of NMDA receptor functions. Indeed, we demonstrated that MK-801 at a low dose of $0.033 \mathrm{mg} / \mathrm{kg}$ decreased the Akt activity by reducing pAktSer473; at medium dose of $0.1 \mathrm{mg} / \mathrm{kg}$, it increased the activity of GSK-3 $\beta$ by decreasing both pGSK$3 \beta$ Ser9 and pAktSer473; whereas at high dose of $1.0 \mathrm{mg} / \mathrm{kg}$, it not only dramatically reduced the levels of pAktSer473 and pGSK-3 $\beta$ Ser9, but it also reduced the total protein levels of Akt and GSK-3 $\beta$. These data may help explain findings reported in previous studies that both pGSK3 and total 
GSK3 were reduced in schizophrenia postmortem brain (Emamian et al, 2004; Kozlovsky et al, 2000, 2002; Nadri et al, 2004).

Importantly, similar to clozapine treatment, LY379268 reversed the actions of MK-801 on Akt and GSK-3 $\beta$ activities. Acute LY379268 at low dose of $0.3 \mathrm{mg} / \mathrm{kg}$ significantly increased the levels of pGSK-3 $\beta$ Ser9 and pAktSer473, indicating a decrease of GSK-3 $\beta$ activity. By doing so, it can offset the increased Akt and GSK-3 $\beta$ activity induced by low and medium doses of MK-801. Furthermore, LY379268 significantly enhanced NMDA-induced current in the prefrontal cortical neurons, and the GSK- $3 \beta$ inhibitor occluded this effect under both in vitro and in vivo conditions. These data suggest that LY379268 at a relatively low dose may regulate the expression and phosphorylation of NMDA receptors by directly decreasing the activity of GSK-3 $\beta$ through enhancing the pAktSer473 and/or pGSK$3 \beta$ Ser9. Our results are consistent with recent evidence showing that antipsychotic agents can decrease GSK-3 $\beta$ activity by increasing the phosphorylation of Akt and GSK$3 \beta$ Ser9 (Emamian et al, 2004; Li et al, 2007). However, at a higher dosage, LY379268's effects on the Akt and GSK activity seemed to be more complicated and, probably unspecific, although it also effectively reversed the expression of NMDA receptors. At a dose of $3.0 \mathrm{mg} / \mathrm{kg}$, it not only significantly increased the pGSK-3 $\beta$ Ser9 but also increased the total protein level of Akt, suggesting a clear reduction of GSK- $3 \beta$ activity. This seems to be odd because a high dose of MK-801 $(1.0 \mathrm{mg} / \mathrm{kg})$ also significantly decreases the activities of both Akt and GSK-3 $\beta$. Obviously other mechanism(s) may be involved in the regulation of NMDA receptor functions under high-dose LY379268 application and further study is needed. Particularly, it is necessary to examine a clinic-relevant dose of mGluR2/3 agonist in the treatment of schizophrenia behaviors and to identify whether behavioral effects of mGluR $2 / 3$ agonists are directly associated with NMDA receptor dysfunctions.

It is known that GSK-3 $\beta$ can be indirectly inhibited via regulation of several intracellular signaling cascades, including the canonical Wnt, Reelin, and tyrosine kinase receptor (Trk)-phosphoinositide 3'-kinase (PI3k)-Akt. Recently, direct inhibition of GSK-3 $\beta$ has emerged as a possible option in the pharmacotherapy of several neuropsychiatric disorders, including schizophrenia. We have demonstrated that the mGluR2/3 agonist, like the D2 antipsychotic agents, is able to reverse the effects of MK-801 by increasing the expression of NMDA receptors in the prefrontal neurons via compensatory regulation of the impaired function of the Akt/GSK-3 $\beta$ signaling pathway. The Akt/GSK-3 $\beta$ signaling cascade was recently identified as being particularly important in mediating D2-associated behaviors and prefrontal cortical functions (Arguello and Gogos, 2008; Beaulieu et al, 2007a,b; Beaulieu et al, 2005; Tan et al, 2008) and in hyperdopamine/D2 receptormediated regulation of NMDA receptor trafficking (Li et al, 2009). This study thus provides novel evidence for the cellular and molecular mechanisms of mGluR2/3 regulation of NMDA receptors and presents useful insights into the mechanistic actions of mGluR2/3 agonists as potential antipsychotic agents for the treatment of schizophrenia. Specifically, in contrast to the widely proposed mechanism of modulating presynaptic glutamate release, our results strongly argue that mGluR2/3 agonists modulate the function of NMDA receptors through postsynaptic actions and reverse the MK-801-induced NMDA dysfunction via the Akt/GSK-3 $\beta$ pathway.

\section{ACKNOWLEDGEMENTS}

This study was supported by a NARSAD (National Alliance for Research on Schizophrenia and Depression) young investigator award and NIH grants R21 MH232307, and R01 MH232395 to W-J Gao.

\section{AUTHOR CONTRIBUTIONS}

WJG conceived the study, supervised the project, and wrote the manuscript. DX carried out most of the experiments and analysis of western blots and immunoprecipitation. YCL carried out the electrophysiologic experiments, western blots, and immunoprecipitation. MAS, RYG, and AEA conducted the behavioral test. JSS supervised the behavioral test. MAS also designed and supervised the entire process of behavioral test, carried out western blots, and proof read the manuscript.

\section{DSICLOSURE}

The authors declare no conflict of interest.

\section{REFERENCES}

Ahn YM, Seo MS, Kim SH, Kim Y, Yoon SC, Juhnn YS et al (2005). Increased phosphorylation of Ser473-Akt, Ser9-GSK-3beta and Ser133-CREB in the rat frontal cortex after MK-801 intraperitoneal injection. Int J Neuropsychopharmacol 8: 607-613.

Akbarian S, Sucher NJ, Bradley D, Tafazzoli A, Trinh D, Hetrick $\mathrm{WP}$ et al (1996). Selective alterations in gene expression for NMDA receptor subunits in prefrontal cortex of schizophrenics. J Neurosci 16: 19-30.

Arguello PA, Gogos JA (2008). A signaling pathway AKTing up in schizophrenia. J Clin Invest 118: 2018-2021.

Arvanov VL, Liang X, Schwartz J, Grossman S, Wang RY (1997). Clozapine and haloperidol modulate N-methyl-D-aspartate- and non-N-methyl-D-aspartate receptor-mediated neurotransmission in rat prefrontal cortical neurons in vitro. I Pharmacol Exp Ther 283: 226-234.

Barbon A, Fumagalli F, La Via L, Caracciolo L, Racagni G, Andrea Riva $M$ et al (2007). Chronic phencyclidine administration reduces the expression and editing of specific glutamate receptors in rat prefrontal cortex. Exp Neurol 208: 54-62.

Barki-Harrington L, Elkobi A, Tzabary T, Rosenblum K (2009). Tyrosine phosphorylation of the $2 \mathrm{~B}$ subunit of the NMDA receptor is necessary for taste memory formation. J Neurosci 29: 9219-9226.

Barria A, Malinow R (2005). NMDA receptor subunit composition controls synaptic plasticity by regulating binding to CaMKII. Neuron 48: 289-301.

Beaulieu J-M, Gainetdinov RR, Caron MG (2007a). The Akt-GSK-3 signaling cascade in the actions of dopamine. Trends Pharmacol Sci 28: 166-172.

Beaulieu J-M, Tirotta E, Sotnikova TD, Masri B, Salahpour A, Gainetdinov RR et al (2007b). Regulation of Akt signaling by D2 and D3 dopamine receptors in vivo. J Neurosci 27: 881-885.

Beaulieu JM, Sotnikova TD, Marion S, Lefkowitz RJ, Gainetdinov RR, Caron MG (2005). An Akt/beta-arrestin 2/PP2A signaling 
complex mediates dopaminergic neurotransmission and behavior. Cell 122: 261-273.

Benneyworth MA, Xiang Z, Smith RL, Garcia EE, Conn PJ, Sanders-Bush E (2007). A selective positive allosteric modulator of metabotropic glutamate receptor subtype 2 blocks a hallucinogenic drug model of psychosis. Mol Pharmacol 72: 477-484.

Blumcke I, Behle K, Malitschek B, Kuhn R, Knopfel T, Wolf HK et al (1996). Immunohistochemical distribution of metabotropic glutamate receptor subtypes mGluR1b, mGluR2/3, mGluR4a and mGluR5 in human hippocampus. Brain Res 736: 217-226.

Cartmell J, Monn JA, Schoepp DD (1999). The metabotropic glutamate $2 / 3$ receptor agonists LY354740 and LY379268 selectively attenuate phencyclidine versus d-amphetamine motor behaviors in rats. J Pharmacol Exp Ther 291: 161-170.

Cartmell J, Monn JA, Schoepp DD (2000a). Attenuation of specific PCP-evoked behaviors by the potent mGlu2/3 receptor agonist, LY379268 and comparison with the atypical antipsychotic, clozapine. Psychopharmacology (Berl) 148: 423-429.

Cartmell J, Schoepp DD (2000b). Regulation of neurotransmitter release by metabotropic glutamate receptors. J Neurochem 75 : 889-907.

Chartoff EH, Heusner CL, Palmiter RD (2005). Dopamine is not required for the hyperlocomotor response to NMDA receptor antagonists. Neuropsychopharmacol 30: 1324-1333.

Chen BS, Roche KW (2007a). Regulation of NMDA receptors by phosphorylation. Neuropharmacology 53: 362-368.

Chen P, Gu Z, Liu W, Yan Z (2007b). Glycogen synthase knase 3 regulates NMDA receptor channel trafficking and function in cortical neurons. Mol Pharmacol 72: 40-51.

Conn PJ, Lindsley CW, Jones CK (2009). Activation of metabotropic glutamate receptors as a novel approach for the treatment of schizophrenia. Trends Pharmacol Sci 30: 25-31.

Conn PJ, Tamminga C, Schoepp DD, Lindsley C (2008). Schizophrenia: moving beyond monoamine antagonists. Mol Interv 8: 99-107.

Coyle JT, Tsai G, Goff D (2003). Converging evidence of NMDA receptor hypofunction in the pathophysiology of schizophrenia. Ann N Y Acad Sci 1003: 318-327.

Cull-Candy SG, Leszkiewicz DN (2004). Role of distinct NMDA receptor subtypes at central synapses. Sci STKE 2004: re16.

Cunningham MO, Hunt J, Middleton S, LeBeau FE, Gillies MJ, Davies CH et al (2006). Region-specific reduction in entorhinal gamma oscillations and parvalbumin-immunoreactive neurons in animal models of psychiatric illness. J Neurosci 26: 2767-2776.

De Sarno P, Bijur GN, Zmijewska AA, Li X, Jope RS (2006). In vivo regulation of GSK3 phosphorylation by cholinergic and NMDA receptors. Neurobiol Aging 27: 413-422.

Dickerson J, Sharp FR (2006). Atypical antipsychotics and a Src kinase inhibitor (PP1) prevent cortical injury produced by the psychomimetic, noncompetitive NMDA receptor antagonist MK-801. Neuropsychopharmacol 31: 1420-1430.

Emamian ES, Hall D, Birnbaum MJ, Karayiorgou M, Gogos JA (2004). Convergent evidence for impaired AKT1-GSK3beta signaling in schizophrenia. Nat Genet 36: 131-137.

Enz R (2007). The trick of the tail: protein-protein interactions of metabotropic glutamate receptors. Bioessays 29: 60-73.

Farber NB (2003). The NMDA receptor hypofunction model of psychosis. Annals NY Acad Sci 1003: 119-130.

Farber NB, Newcomer JW, Olney JW (1998). The glutamate synapse in neuropsychiatric disorders. Focus on schizophrenia and Alzheimer's disease. Prog Brain Res 116: 421-437.

Farber NB, Wozniak DF, Price MT, Labruyere J, Huss J, St Peter H et al (1995). Age-specific neurotoxicity in the rat associated with NMDA receptor blockade: potential relevance to schizophrenia? Biol Psychiatry 38: 788-796.

Fell MJ, Johnson BG, Svensson KA, Schoepp DD (2008). Evidence for the role of mGlu2 not mGlu3 receptors in the pre-clinical antipsychotic pharmacology of the mGlu2/3 receptor agonist LY404039. J Pharmacol Exp Ther 326: 209-217.

Fell MJ, Perry KW, Falcone JF, Johnson BG, Barth VN, Rash KS et al (2009). In vitro and in vivo evidence for a lack of interaction with Dopamine D2 receptors by the mGlu2/3 receptor agonists LY354740 and LY379268. J Pharmacol Exp Ther 331: $1126-1136$.

Gao XM, Tamminga CA (1995). MK801 induces late regional increases in NMDA and kainate receptor binding in rat brain. J Neural Transm Gen Sect 101: 105-113.

Gonzalez-Maeso J, Ang RL, Yuen T, Chan P, Weisstaub NV, Lopez-Gimenez JF et al (2008). Identification of a serotonin/ glutamate receptor complex implicated in psychosis. Nature 452: 93-97.

Harris LW, Sharp T, Gartlon J, Jones DN, Harrison PJ (2003). Long-term behavioural, molecular and morphological effects of neonatal NMDA receptor antagonism. Eur J Neurosci 18: 1706-1710.

Harrison PJ (2008). Metabotropic glutamate receptor agonists for schizophrenia. Br J Psychiatry 192: 86-87.

Hashimoto T, Volk DW, Eggan SM, Mirnics K, Pierri JN, Sun Z et al (2003). Gene expression deficits in a subclass of GABA neurons in the prefrontal cortex of subjects with schizophrenia. J Neurosci 23: 6315-6326.

Homayoun H, Jackson ME, Moghaddam B (2005). Activation of metabotropic glutamate $2 / 3$ receptors reverses the effects of nmda receptor hypofunction on prefrontal cortex unit activity in awake rats. J Neurophysiol 93: 1989-2001.

Imre G (2007). The preclinical properties of a novel group II metabotropic glutamate receptor agonist LY379268. CNS Drug Rev 13: 444-464.

Itokawa M, Yamada K, Yoshitsugu K, Toyota T, Suga T, Ohba $\mathrm{H}$ et al (2003). A microsatellite repeat in the promoter of the $\mathrm{N}$-methyl-D-aspartate receptor 2A subunit (GRIN2A) gene suppresses transcriptional activity and correlates with chronic outcome in schizophrenia. Pharmacogenetics 13: 271-278.

Jackson ME, Homayoun H, Moghaddam B (2004). NMDA receptor hypofunction produces concomitant firing rate potentiation and burst activity reduction in the prefrontal cortex. Proc Natl Acad Sci USA 101: 8467-8472.

Javitt DC (2004). Glutamate as a therapeutic target in psychiatric disorders. Mol Psychiatry 9: 984-997.

Javitt DC, Zukin SR (1991). Recent advances in the phencyclidine model of schizophrenia. Am J Psychiatry 148: 1301-1308.

Jentsch JD, Roth RH (1999). The neuropsychopharmacology of phencyclidine: from NMDA receptor hypofunction to the dopamine hypothesis of schizophrenia. Neuropsychopharmacol 20: 201-225.

Jope RS, Roh MS (2006). Glycogen synthase kinase-3 (GSK3) in psychiatric diseases and therapeutic interventions. Curr Drug Targets 7: 1421-1434.

Kinney JW, Davis CN, Tabarean I, Conti B, Bartfai T, Behrens MM (2006). A specific role for NR2A-containing NMDA receptors in the maintenance of parvalbumin and GAD67 immunoreactivity in cultured interneurons. J Neurosci 26: 1604-1615.

Koros E, Dorner-Ciossek C (2007). The role of glycogen synthase kinase-3beta in schizophrenia. Drug News Perspect 20: 437-445.

Kozlovsky N, Belmaker RH, Agam G (2000). Low GSK-3beta immunoreactivity in postmortem frontal cortex of schizophrenic patients. Am J Psychiatry 157: 831-833.

Kozlovsky N, Belmaker RH, Agam G (2002). GSK-3 and the neurodevelopmental hypothesis of schizophrenia. Eur Neuropsychopharmacol 12: 13-25.

Kozlovsky N, Nadri C, Agam G (2005). Low GSK-3beta in schizophrenia as a consequence of neurodevelopmental insult. Eur Neuropsychopharmacol 15: 1-11.

Kristiansen LV, Huerta I, Beneyto M, Meador-Woodruff JH (2007). NMDA receptors and schizophrenia. Curr Opin Pharmacol 7: 48-55. 
Kristiansen LV, Patel SA, Haroutunian V, Meador-Woodruff JH (2010). Expression of the NR2B-NMDA receptor subunit and its Tbr-1/CINAP regulatory proteins in postmortem brain suggest altered receptor processing in schizophrenia. Synapse 64: 495-502.

Krystal JH, D'Souza DC, Petrakis IL, Belger A, Berman RM, Charney DS et al (1999). NMDA agonists and antagonists as probes of glutamatergic dysfunction and pharmacotherapies in neuropsychiatric disorders. Harv Rev Psychiatry 7: 125-143.

Krystal JH, Karper LP, Seibyl JP, Freeman GK, Delaney R, Bremner JD et al (1994). Subanesthetic effects of the noncompetitive NMDA antagonist, ketamine, in humans. Psychotomimetic, perceptual, cognitive, and neuroendocrine responses. Arch Gen Psychiatry 51: 199-214.

Lahti AC, Koffel B, LaPorte D, Tamminga CA (1995). Subanesthetic doses of ketamine stimulate psychosis in schizophrenia. Neuropsychopharmacol 13: 9-19.

Lau CG, Zukin RS (2007). NMDA receptor trafficking in synaptic plasticity and neuropsychiatric disorders. Nat Rev Neurosci 8: 413-426.

Lei G, Xia Y, Johnson KM (2008). The role of Akt-GSK-3beta signaling and synaptic strength in phencyclidine-induced neurodegeneration. Neuropsychopharmacology 33: 1343-1353.

Li X, Rosborough KM, Friedman AB, Zhu W, Roth KA (2007). Regulation of mouse brain glycogen synthase kinase- 3 by atypical antipsychotics. Int J Neuropsychopharmacol 10: 7-19.

Li YC, Xi D, Roman J, Huang YQ, Gao WJ (2009). Activation of glycogen synthase kinase-3 beta is required for hyperdopamine and D2 receptor-mediated inhibition of synaptic NMDA receptor function in the rat prefrontal cortex. J Neurosci 29: 15551-15563.

Liao GY, Wagner DA, Hsu MH, Leonard JP (2001). Evidence for direct protein kinase-C mediated modulation of N-methylD-aspartate receptor current. Mol Pharmacol 59: 960-964.

Lindahl JS, Keifer J (2004). Glutamate receptor subunits are altered in forebrain and cerebellum in rats chronically exposed to the NMDA receptor antagonist phencyclidine. Neuropsychopharmacology 29: 2065-2073.

Lisman JE, Coyle JT, Green RW, Javitt DC, Benes FM, Heckers S et al (2008). Circuit-based framework for understanding neurotransmitter and risk gene interactions in schizophrenia. Trends Neurosci 31: 234-242.

Liu XB, Munoz A, Jones EG (1998). Changes in subcellular localization of metabotropic glutamate receptor subtypes during postnatal development of mouse thalamus. J Comp Neurol 395: $450-465$.

Liu XY, Chu XP, Mao LM, Wang M, Lan HX, Li MH et al (2006). Modulation of D2R-NR2B interactions in response to cocaine. Neuron 52: 897-909.

Luo HR, Hattori H, Hossain MA, Hester L, Huang Y, Lee-Kwon W et al (2003). Akt as a mediator of cell death. Proc Natl Acad Sci USA 100: 11712-11717.

Luthi A, Schwyzer L, Mateos JM, Gahwiler BH, McKinney RA (2001). NMDA receptor activation limits the number of synaptic connections during hippocampal development. Nat Neurosci 4: 1102-1107.

Marino MJ, Conn PJ (2002). Direct and indirect modulation of the N-methyl D-aspartate receptor. Curr Drug Targets CNS Neurol Disord 1: 1-16.

Matthews DB, Kralic JE, Devaud LL, Fritschy JM, Marrow AL (2000). Chronic blockade of N-methyl-D-aspartate receptors alters gamma-aminobutyric acid type A receptor peptide expression and function in the rat. J Neurochem 74: 1522-1528.

Meador-Woodruff JH, Healy DJ (2000). Glutamate receptor expression in schizophrenic brain. Brain Res Brain Res Rev 31: 288-294.

Millan MJ (2005). N-Methyl-D-aspartate receptors as a target for improved antipsychotic agents: novel insights and clinical perspectives. Psychopharmacology (Berl) 179: 30-53.
Moghaddam B (2003). Bringing order to the glutamate chaos in schizophrenia. Neuron 40: 881-884.

Moghaddam B (2004). Targeting metabotropic glutamate receptors for treatment of the cognitive symptoms of schizophrenia. Psychopharmacology (Berl) 174: 39-44.

Moghaddam B, Adams BW (1998). Reversal of phencyclidine effects by a group II metabotropic glutamate receptor agonist in rats. Science 281: 1349-1352.

Nadri C, Dean B, Scarr E, Agam G (2004). GSK-3 parameters in postmortem frontal cortex and hippocampus of schizophrenic patients. Schizophr Res 71: 377-382.

Nadri C, Lipska BK, Kozlovsky N, Weinberger DR, Belmaker RH, Agam G (2003). Glycogen synthase kinase (GSK)-3beta levels and activity in a neurodevelopmental rat model of schizophrenia. Brain Res Dev Brain Res 141: 33-37.

Nakki R, Sharp FR, Sagar SM, Honkaniemi J (1996). Effects of phencyclidine on immediate early gene expression in the brain. J Neurosci Res 45: 13-27.

Ninan I, Jardemark KE, Wang RY (2003). Olanzapine and clozapine but not haloperidol reverse subchronic phencyclidine-induced functional hyperactivity of N-methyl-D-aspartate receptors in pyramidal cells of the rat medial prefrontal cortex. Neuropharmacology 44: 462-472.

Oliveira JF, Krügel U, Köles L, Illes P, Wirkner K (2008). Blockade of glutamate transporters leads to potentiation of NMDA receptor current in layer $\mathrm{V}$ pyramidal neurons of the rat prefrontal cortex via group II metabotropic glutamate receptor activation. Neuropharmacology 55: 447-453.

Olney JW, Farber NB (1995). Glutamate receptor dysfunction and schizophrenia. Arch Gen Psychiatry 52: 998-1007.

Olszewski RT, Wegorzewska MM, Monteiro AC, Krolikowski KA, Zhou J, Kozikowski AP et al (2008). Phencyclidine and dizocilpine induced behaviors reduced by $\mathrm{N}$-acetylaspartylglutamate peptidase inhibition via metabotropic glutamate receptors. Biol Psychiatry 63: 86-91.

Patil ST, Zhang L, Martenyi F, Lowe SL, Jackson KA, Andreev BV et al (2007). Activation of $\mathrm{mGlu} 2 / 3$ receptors as a new approach to treat schizophrenia: a randomized Phase 2 clinical trial. Nat Med 13: 1102-1107.

Peineau S, Bradley C, Taghibiglou C, Doherty A, Bortolotto ZA, Wang YT et al (2008). The role of GSK-3 in synaptic plasticity. Br J Pharmacol 153(S1): S428-S437.

Peineau S, Taghibiglou C, Bradley C, Wong TP, Liu L, Lu J et al (2007). LTP inhibits LTD in the hippocampus via regulation of GSK3[beta]. Neuron 53: 703-717.

Petralia RS, Wang YX, Niedzielski AS, Wenthold RJ (1996a). The metabotropic glutamate receptors, MGLUR2 and MGLUR3, show unique postsynaptic, presynaptic and glial localizations. Neuroscience 71: 949-976.

Petralia RS, Wang YX, Zhao HM, Wenthold RJ (1996b). Ionotropic and metabotropic glutamate receptors show unique postsynaptic, presynaptic, and glial localizations in the dorsal cochlear nucleus. J Comp Neurol 372: 356-383.

Recasens M, Guiramand J, Aimar R, Abdulkarim A, Barbanel G (2007). Metabotropic glutamate receptors as drug targets. Curr Drug Targets 8: 651-681.

Rujescu D, Bender A, Keck M, Hartmann AM, Ohl F, Raeder H et al (2006). A pharmacological model for psychosis based on N-methylD-aspartate receptor hypofunction: molecular, cellular, functional and behavioral abnormalities. Biol Psychiatry 59: 721-729.

Schlumberger C, Schafer D, Barberi C, More L, Nagel J, Pietraszek $M$ et al (2009). Effects of a metabotropic glutamate receptor group II agonist LY354740 in animal models of positive schizophrenia symptoms and cognition. Behav Pharmacol 20: 56-66.

Schoepp DD (2001). Unveiling the functions of presynaptic metabotropic glutamate receptors in the central nervous system. J Pharmacol Exp Ther 299: 12-20. 
Seo MS, Kim SH, Ahn YM, Kim Y, Jeon WJ, Yoon SC et al (2007). The effects of repeated administrations of MK-801 on ERK and GSK-3beta signalling pathways in the rat frontal cortex. Int J Neuropsychopharmacol 10: 359-368.

Svenningsson P, Tzavara ET, Carruthers R, Rachleff I, Wattler S, Nehls M et al (2003). Diverse psychotomimetics act through a common signaling pathway. Science 302: 1412-1415.

Swanson CJ, Schoepp DD (2002). The group II metabotropic glutamate receptor agonist (-)-2-oxa-4-aminobicyclo[3.1.0.]hexane-4,6-dicarboxylate (LY379268) and clozapine reverse phencyclidine-induced behaviors in monoamine-depleted rats. J Pharmacol Exp Ther 303: 919-927.

Tan HY, Nicodemus KK, Chen Q, Li Z, Brooke JK, Honea R et al (2008). Genetic variation in AKT1 is linked to dopamineassociated prefrontal cortical structure and function in humans. J Clin Invest 118: 2200-2208.

Tang YP, Shimizu E, Dube GR, Rampon C, Kerchner GA, Zhuo M et al (1999). Genetic enhancement of learning and memory in mice. Nature 401: 63-69.

Thotala DK, Geng L, Dickey AK, Hallahan DE, Yazlovitskaya EM (2010). A new class of molecular targeted radioprotectors: GSK-3beta inhibitors. Int J Radiat Oncol Biol Phys 76: 557-565.

Thotala DK, Hallahan DE, Yazlovitskaya EM (2008). Inhibition of glycogen synthase kinase 3 beta attenuates neurocognitive dysfunction resulting from cranial irradiation. Cancer Res 68: 5859-5868.

Tsukada H, Nishiyama S, Fukumoto D, Sato K, Kakiuchi T, Domino EF (2005). Chronic NMDA antagonism impairs working memory, decreases extracellular dopamine, and increases D1 receptor binding in prefrontal cortex of conscious monkeys. Neuropsychopharmacology 30: 1861-1869.

Turnock-Jones JJ, Jennings CA, Robbins MJ, Cluderay JE, Cilia J, Reid JL et al (2009). Increased expression of the NR2A NMDA receptor subunit in the prefrontal cortex of rats reared in isolation. Synapse 63: 836-846.

Tyszkiewicz JP, Gu Z, Wang X, Cai X, Yan Z (2004). Group II metabotropic glutamate receptors enhance NMDA receptor currents via a protein kinase C-dependent mechanism in pyramidal neurones of rat prefrontal cortex. J Physiol 554(Part 3): 765-777.

Wang C, Showalter VM, Hillman GR, Johnson KM (1999). Chronic phencyclidine increases NMDA receptor NR1 subunit mRNA in rat forebrain. J Neurosci Res 55: 762-769.

Wang H, Stradtman GGr, Wang XJ, Gao WJ (2008). A specialized NMDA receptor function in layer 5 recurrent microcircuitry of the adult rat prefrontal cortex. Proc Natl Acad Sci USA 105: 16791-16796.

Wang HX, Gao WJ (2009). Cell type-specific development of NMDA receptors in the interneurons of rat prefrontal cortex. Neuropsychopharmacology 34: 2028-2040.

Weinberger DR (2007). Schizophrenia drug says goodbye to dopamine. Nat Med 13: 1018-1019.

Winger G, Palmer RK, Woods JH (1989). Drug-reinforced responding: rapid determination of dose-response functions. Drug Alcohol Depend 24: 135-142.

Winter JC, Eckler JR, Rabin RA (2004). Serotonergic/glutamatergic interactions: the effects of mGlu2/3 receptor ligands in rats trained with LSD and PCP as discriminative stimuli. Psychopharmacology (Berl) 172: 233-240.

Wittmann M, Marino MJ, Henze DA, Seabrook GR, Conn PJ (2005). Clozapine potentiation of N-Methyl-D-aspartate receptor currents in the nucleus accumbens: role of NR2B and protein kinase A/Src kinases. J Pharmacol Exp Ther 313: 594-603.

Woo TU, Walsh JP, Benes FM (2004). Density of glutamic acid decarboxylase 67 messenger RNA-containing neurons that express the $\mathrm{N}$-methyl-D-aspartate receptor subunit NR2A in the anterior cingulate cortex in schizophrenia and bipolar disorder. Arch Gen Psychiatry 61: 649-657.

Woolley ML, Pemberton DJ, Bate S, Corti C, Jones DN (2008). The mGlu2 but not the mGlu3 receptor mediates the actions of the mGluR2/3 agonist, LY379268, in mouse models predictive of antipsychotic activity. Psychopharmacology (Berl) 196: 431-440.

Xi D, Keeler B, Zhang W, Houle JD, Gao WJ (2009a). NMDA receptor subunit expression in GABAergic interneurons in the prefrontal cortex: application of laser micro dissection technique. J Neurosci Meth 176: 172-181.

Xi D, Zhang W, Wang HX, Stradtman GG, Gao WJ (2009b). Dizocilpine (MK-801) induces distinct changes of N-methyl-daspartic acid receptor subunits in parvalbumin-containing interneurons in young adult rat prefrontal cortex. Int $J$ Neuropsychopharmacol 12: 1395-1408.

Zhang S, Edelmann L, Liu J, Crandall JE, Morabito MA (2008). Cdk5 regulates the phosphorylation of tyrosine 1472 NR2B and the surface expression of NMDA receptors. J Neurosci 28: 415-424.

Zhu L-Q, Wang S-H, Liu D, Yin Y-Y, Tian Q, Wang X-C et al (2007). Activation of glycogen synthase kinase-3 inhibits longterm potentiation with synapse-associated impairments. J Neurosci 27: 12211-12220.

Supplementary Information accompanies the paper on the Neuropsychopharmacology website (http://www.nature.com/npp) 